\title{
The diversity of saproxylic beetles' community from the Natural Reserve Voievodeasa Forest, North-Eastern Romania
}

\author{
Nicolai Olenici ${ }^{1}$, Ecaterina Fodor ${ }^{2}$
}

Olenici N., Fodor E., 2021. The diversity of saproxylic beetles' community from the Natural Reserve Voievodeasa Forest, North-Eastern Romania. Ann. For. Res. 64(1): 31-60.

Abstract Nature reserves harbour considerable richness and diversity of saproxylic organisms since dead wood is preserved in situ, this being also the case of Voivodeasa beech-spruce-fir forest in North-Eastern Romania, the area investigated under the present research. Flight interception traps were employed to capture insects during a vegetation season with the goal to characterize saproxylic Coleoptera community in terms of diversity and several other structural features. Among the captured insects, the majority pertained to obligate saproxylic species (217 species). However, the unexpected high species richness corresponded to an area with modest representation of deadwood due to previous status of commercial forest. The identified beetles were members of different habitat-guilds depending on what type of substrate they colonized: recently dead wood $(23 \%)$, decomposed dead wood (41\%), wood inhabiting fungi $(34 \%)$ and treehollow detritus $(2 \%)$. According to their trophic position, the identified saproxylic beetles pertained to the following guilds: xylophagous $(40 \%)$, mycetophagous $(39 \%)$, predatory $(14 \%)$, and species relying on other food resources. The observed richness corresponded to the case of hyperdiverse communities where sampling never leads to the stabilization of species richness under a realistic sampling scheme. The diversity profiles constructed on Shannon, Gini-Simpson, Berger-Parker and evenness indices for the pooled inventory and for separate samples across the vegetation season indicated the aggregated saproxylic community as highly diverse and highly uneven, with rich representation of rare species, dominated by few abundant species. We assembled four bipartite, unweighted, and undirected networks to approach the temporal changes across the sampling period extended over one vegetation season. The topology of beetles' community and of the three main trophic guilds (xylophagous, mycetophagous and predatory) networks linked to time sequences are characterized by high connectance, high nestedness and modularity, with the exception of the mycetophagous sub-network not displaying significant modularity. Among the identified species, $13 \%$ indicate high degree of naturalness of the Voievodeasa forest. 62 of the identified species are included in the Red List of European Saproxylic Beetles of which five are near threatened (Protaetia fieberi, Cucujus cinnaberinus, Crepidophorus mutilatus, Ceruchus chrysomelinus, Prostomis mandibularis), Ischnodes sanguinolentus is vulnerable and Rhysodes sulcatus is an endangered species. During the 
study, two Coleoptera species, new for Romanian insect fauna were identified: Denticollis interpositus Roubal, 1941 and Hylis procerulus (Mannerheim 1823).

Keywords: saproxylic beetles, Voievodeasa forest nature reserve, species richness, diversity profiles, time dependent network of saproxylic beetles, protected species, new species records.

Addresses: ${ }^{1}$ National Institute for Research and Development in Forestry 'Marin Dracea', SCDEP Campulung Moldovenesc, Romania| ${ }^{2}$ Department of Forestry and Forest Engineering, Faculty of Environmental Protection, University of Oradea, Romania.

$\square$ Corresponding Author: Ecaterina Fodor (ecaterina.fodor@gmail.com).

Manuscript received February 8, 2021; revised June 6, 2021; accepted June 12, 2021.

\section{Introduction}

Dead wood is a main component of the forest ecosystems with several important roles addressing biodiversity, nutrient cycling, energy flows, with wood decomposition as key ecosystem level process (Speigh 1989, Grove 2002, Stokland et al. 2012, RamírezHernández et al. 2019). Dead and decaying wood apart from playing a central role in forest ecosystems, are also naturalness indicators as they are sensitive to habitat modifications and management practices (Albrecht 1991, Radu 2007, Lassauce et al. 2011, Kunttu et al. 2015). The microhabitats they harbour are ephemeral and exposed to disturbances under natural conditions but especially under anthropogenic interventions (Grove 2002). Saproxylic species that are dependent on dead or dying wood (Speigh 1989) but also on wounded wood from weakened or dead trees (Stockland et al. 2012), establish complex interaction networks and are key contributors to forest biodiversity and processes.

In commercial forests, deadwood is considerably under-represented, with different allocation to size and decomposition classes, and follows different production and decomposition dynamics compared to natural forests (Jonsson \& Siitonen 2012). European forests, with their long history of intensive use contain relatively few undisturbed patches to support saproxylic communities (Grove 2002). Moreover, dead and dying wood represent a category of spatial-temporal, unpredictable resource, a feature that influences the composition and abundances of saproxylic beetles' guilds (Nitzu \& Olenici 2009, Wende et al. 2017). Consequently, the survival of the whole spectrum of species depending on this type of resource and habitat encompassing numerous microhabitats is compromised in commercial forests (Stokland 2012, Ulyshen 2018), putting at risk nutrient cycling due to the declining saproxylic beetles' diversity (Stockland et al. 2012, Wende et al. 2017). Nevertheless, putting these forests under protection does not restore the biodiversity of saproxylic organisms comparable to unmanaged natural forests even when there is some quantity of dead wood preserved. In this context, the estimation of the degree of forest naturalness have to take into consideration saproxylic organisms, which largely depend on the stands' management history. Since the availability of deadwood is a limiting factor for saproxylic organisms, it is currently considered that the amount of deadwood should be increased in order to protect biodiversity (Gossner et al. 2013, Seibold et al. 2014). There is an increasing body of information on the positive correlation between species richness of saproxylic beetles and the quantity 
of different categories of dead wood (Seibold et al. 2015). However, contrasting results are also reported, showing that there is no statistical confirmation for this dependence at least when comparing managed forests with old-growth or pristine forests (Chumak et al. 2015).

Among the saproxylic organisms, insects are the most numerous group and among these, species-rich saproxylic beetles (Stokland \& Siitonen 2012, Gimmel \& Ferro 2018) are particularly valuable indicators of the forest naturalness (Müller et al. 2005, Lachat et al. 2012, Eckelt et al. 2018). The main contribution to detritic food web based of decomposing wood of saproxylic beetles consists in the mechanical breakdown of the woody debris (Hickin 1963).

Community structure of saproxylic insects and particularly beetles was addressed by numerous studies due to high conservation interest of saproxylic guilds. However, the way we define the community plays a huge role in the way we make the interpretation of results, giving a biological meaning to the numbers. The saproxylic beetle community is defined taxonomically and resource-wise, the habitat and the feeding substrate being integrated in what is considered resource. From this functional perspective, the community is a local group of trophically similar species that interact (Hubbell 2005) and may be split in smaller units encompassing species with similar mode of resource use, the guilds (Magurran 2004). The dead-wood accommodates several guilds of saproxylic beetles, from xylophagous to mycophagous and predatory species that build together with other categories of organisms as fungi, bacteria and invertebrates, a complex trophic web (Wende et al. 2017). As wood decomposes, there is a succession of fungi associated to different stages of decay, which, in turn, accommodate insect communities composed of mycetophagous, predatory and parasitoid species (Jonsell et al. 2016).

Addressing biodiversity is an increasingly important topic since it brings sound arguments in favour of conservation of species, habitats and ecosystems but the estimation of biodiversity especially for comparisons is not an easy task both logistically and computationally.

One way to address the subject is to use classical abundance-based indices and infer important community properties from the obtained values. However, the approach is limited not permitting the species assemblages to be compared if species numbers and their abundances differ since the numerical relationship between the two variables is not linear (Tóthmérész \& Magura 2003). From conservation perspective, rare species are important, from pest control perspective when it comes to consider insects, common and dominant species are of interest.

If community structure in terms of species composition, richness, abundance and biodiversity has a long research tradition, network analysis emerged as useful tool only during the last two decades. The network architecture of an ecological community describes the structure of species interactions, which is characteristic for a given type of interaction (Song \& Saavedra 2020). Most of empirical and theoretic ecological bipartite networks addressed mutualistic and antagonistic interactions among species, fewer focused of detritic networks, with insects playing a key role (Quinto et al. 2012, Wende et al. 2017). Generally, biotic interactions' networks are highly structured and the emergent properties can be tackled using network metrics that give insight into community assemblage patterns and dynamics. It was shown that structural attributes of the networks promoted species co-existence and resilience to disturbance (Tylianakis et al. 2010, Ramírez-Hernández 2019)

Several network properties are generally employed in order to characterize and define networks among which connectivity, modularity, and nestedness are the most frequently reported. As spatial and temporal dimensions were important variables 
in assembling deadwood-associated communities, they became a key concern in community ecology of saproxylic organisms (Sverdrup-Thygeson et al. 2014). Accordingly, the temporal variation of species composition reflected by flight interception traps is informative and may be approached from the perspective of bipartite network analysis. Saproxylic beetle communities establish complex networks due to complex interactions that depend on different trophic resources. Therefore, it is preferable to split the aggregated network in sub-networks corresponding to different trophic guilds (Quinto et al. 2012). Time is also a resource managed differently during the life stages of the species and in this context, the network approach in the analysis of species turnover due to phenological change can bring interesting insights in how species spectra of adult beetles evolve across different time windows.

The nature reserves are included among the IUCN categories of protected areas aiming the conservation of biodiversity (Dudley 2008). In the case of forest ecosystems, several factors establish the degree of naturalness: the origin of the forests (natural versus man-established), the composition of the stands (containing autochthonous versus allochthonous tree species), the type of regeneration and recruitment (natural, artificial or mixed), the spatial-temporal continuity (Teodosiu 2014a) and characteristics of the forest structure. The recently established nature reserve Voievodeasa beech-spruce-fir forest in North-Eastern Romania, the area investigated under the present research, contains different categories of deadwood well preserved in situ harbouring high diversity of directly and indirectly dependent organisms. Previous information on plant biodiversity (unpublished data) and forest structural biodiversity (Teodosiu 2014b) was reported, saproxylic beetles remaining an open and important biodiversity topic.

The aims of the current paper consisted in the characterization of saproxylic beetles' community structure using information gathered from flight interception traps in Voievodeasa Forest Natural reserve. We addressed the following objectives: 1) for the specific purposes of the current study, both classical abundance-dominance and diversity indices were used in order to assess the structure of the saproxylic beetles' community. 2) We also assessed the abundance structure and composition of the community change across the time scale of one vegetation season, the employed metrics mirroring the shifts produced in the local community in Voievodeasa forest reserve. 3) Another goal consisted in identifying the important species from the conservation and legal status perspectives. 4) We assessed the variation of the community structure in terms of composition and abundances of three main feeding guilds of the saproxylic beetles' community: xylophagous, mycetophagous and predatory beetles. 5) We characterized the architecture of networks constructed for the pooled saproxylic community and for the main trophic guilds considering the shifts in species composition produced in the confines of one vegetation season. 6) We aimed to highlight from conservation perspective the important saproxylic beetles, identified in Voievodeasa Nature Reserve, demonstrating the importance for biodiversity of protected forests with high degree of naturalness.

The obtained information will help for the future assessment of the structure of the saproxylic beetles' community under different management regimes compared to high naturalness forest of similar composition.

\section{Materials and Methods}

\section{Study area}

The protected area Voievodeasa beech-sprucefir forest is situated in North-Eastern Romania $\left(47.812-47.826^{\circ} \mathrm{N} ; 25.685-25.705^{\circ} \mathrm{E}\right)$, in Suceava County. The forest has acquired the 
status of nature reserve in 2007. The Forest District Marginea administrates the forest covering an area of 101.9 ha, vegetating on a hilly terrain, on predominantly south-eastern mild slopes (Table 1). The sampling sites were established within the management unit 5A (main structural characteristics enumerated by Teodosiu 2014b) covering 43\% of reserve's area (Anonymous 2010). We classified the dead wood in three categories: fresh dead wood, decomposing dead wood and advanced decomposed dead wood adapting the largely used classification of Franc et al. (2007).

A previous study showed that lying deadwood represented 11\%, and standing deadwood represented nearly $3 \%$ of the standing wood volume in the main tree stands of the reserve (Teodosiu 2014b). In both inventoried management units, $5 \mathrm{~A}$ and $5 \mathrm{~B}$, the deadwood dominant size class corresponded to diameters less than $20 \mathrm{~cm}$ and lengths reaching nearly $200 \mathrm{~cm}$.

Concerning the history of stand management previous to the establishment of the protected area, data from the management plans corresponding to $30-40$ years back document minor silvicultural interventions consisting in wood harvesting in the range of 75 to $600 \mathrm{~m}^{3 /}$ ha/decade (Teodosiu 2014b).

Table 1 Site and forest stand characteristics of management units corresponding to Voievodeasa Forest nature reserve (Forest district Marginea, Production Unit II, Bercheza).

\begin{tabular}{|c|c|c|c|c|c|c|c|c|c|}
\hline No & $\begin{array}{c}\text { Management } \\
\text { unit }\end{array}$ & $\begin{array}{c}\text { Area } \\
\text { (ha) }\end{array}$ & $\begin{array}{c}\text { Habitat } \\
\text { type }\end{array}$ & $\begin{array}{c}\text { Altitude } \\
(\mathrm{m})\end{array}$ & Exposition & $\begin{array}{l}\text { Slope } \\
\text { (g) }\end{array}$ & Composition \% & $\begin{array}{c}\text { Age } \\
\text { (years) }\end{array}$ & $\begin{array}{c}\text { Canopy } \\
\text { cover }\end{array}$ \\
\hline 1. & $4 \mathrm{~B}$ & 32.8 & R4101 & $590-750$ & SE & 16 & $\begin{array}{l}50 \text { A. alba } \\
40 \text { P. abies } \\
10 \text { F. sylvatica }\end{array}$ & 110 & 0.6 \\
\hline 2. & $4 \mathrm{H}$ & 0.2 & R4101 & 760 & SE & 14 & $\begin{array}{l}70 \mathrm{~A} \text {. alba } \\
30 \mathrm{~F} \text {. sylvatica }\end{array}$ & 25 & 0.7 \\
\hline 3. & $4 \mathrm{I}$ & 0.9 & R4102 & 700 & S & 12 & $\begin{array}{l}50 \mathrm{~A} . \text { alba } \\
50 \mathrm{~F} \text {. sylvatica }\end{array}$ & 20 & 0.7 \\
\hline 4. & $5 \mathrm{~A}$ & 44.2 & R4109 & $700-900$ & SE & 18 & $\begin{array}{l}90 \mathrm{~F} \text {. sylvatica } \\
10 \mathrm{~A} \text {. alba }\end{array}$ & 120 & $0.7^{*}$ \\
\hline 5. & $5 \mathrm{~B}$ & 23.2 & R4101 & $590-750$ & SE & 16 & $\begin{array}{l}60 \text { P. abies } \\
30 \text { A. alba } \\
10 \text { F. sylvatica }\end{array}$ & 120 & 0.7 \\
\hline 6. & $5 \mathrm{E}$ & 0.6 & R4101 & 700 & SE & 14 & $\begin{array}{l}40 \mathrm{~F} \text {. sylvatica } \\
30 \mathrm{P} \text {. abies } \\
30 \mathrm{~A} \text {. alba }\end{array}$ & 25 & 0.9 \\
\hline
\end{tabular}

Total 101.9

Habitat type (Doniță et al. 2005): R4101 - 'South-Eastern Carpathian forests with Picea abies, Fagus sylvatica, Abies alba and Pulmonaria rubra'; R4102 - 'South-Eastern Carpathian forests with Picea abies, Fagus sylvatica, Abies alba and Hieracium rotundatum'; R4109 - 'South-Eastern Carpathian beech forests (Fagus sylvatica) with Symphytum cordatum'.

*) In some places, the canopy cover was sparse, the soil being covered by a dense herb layer, a fact that explained the presence of Diachromus germanus, a species not characteristic for forests. 


\section{Sampling design and identification}

Sampling design consisted of an array of 20 window traps (flight interception traps) in a square grid $(100 \times 100 \mathrm{~m})$, placed within management unit 5A (Fig. 1).

The window traps were assembled using two crossed polyethylene foils fixed in $40 \mathrm{x}$ $60 \mathrm{~cm}$ wire window. A conical funnel of $40 \mathrm{~cm}$ diameter and $40 \mathrm{~cm}$ height was attached beneath the frames to collect the insects into a plastic, 1-liter bottle partially filled with a mixture of water, salt and a small amount of detergent. The traps were suspended by plastic wires tied to tree stems, at least at one-meter distance from a tree, maintaining one meter off the ground level of the collecting funnel (Fig. 2). To avoid the clogging of the collecting bottle with falling leaves, a plastic cap of $60 \mathrm{~cm}$ diameter was fixed above the window frames.

Previous studies have shown that the window traps were efficient in the interception of a large proportion of the forest beetles, between 44 and $48.3 \%$, being a specifically reliable method in intercepting threatened species (Muona 1999, Martikainen \& Kouki 2003).

The traps intercepted flying insects between 10.05 and 26.09.2011, which were collected every two weeks. Beetles were conserved separately from the bulk of the catch in ethylic alcohol of $96^{\circ}$ and refrigerated at $0^{\circ} \mathrm{C}$ until identification.

The first author performed the species identification, based on reference papers for the order Coleoptera; for the identification of Scolytinae beetles we employed the paper of Pfeffer (1995), species of fam. Cerambycidae were identified using the published keys of Bense (1995), species of fam. Cleridae were identified using the published key of Gerstmeier (1998). Beetles from other families were identified using keys published in volumes 'Die Käfer Mitteleuropas' (Freude et al. 1966-2009, Lohse \& Lucht 1989-1994, Lucht \& Klausnitzer 1998, Assing \& Schülke 2011), partially revised by Lompe (2002).
Nomenclature and classification of families, sub-families, genera and sub-genera followed BioLib database (Zicha 1999-2021).

Allocation of species according to substrate and food preferences followed the information published by Koch (1989-1992), Schmidl \& Bussler (2004), and Hyvärinen (2006). Inclusion and classification of insect species as relicts of old-growth forests followed Müller et al. (2005) and Eckelt et al. (2018). Categories of species endangerment followed the classifications of Red List of European Saproxylic Coleoptera (Nieto \& Alexander 2010, Cálix et al. 2018) and the List of Endangered Species from Carpathian Mountains (Witkowski et al. 2003).

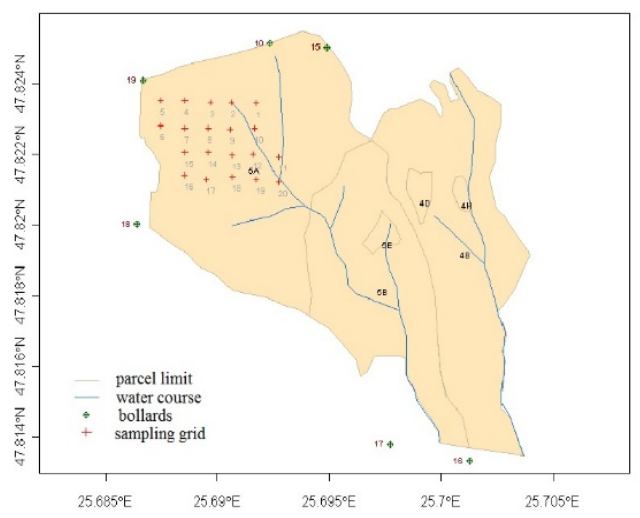

Figure 1 The map of the sampled area included in management unit 5A (part of Voievodeasa nature reserve) with the grid of flight interception traps.

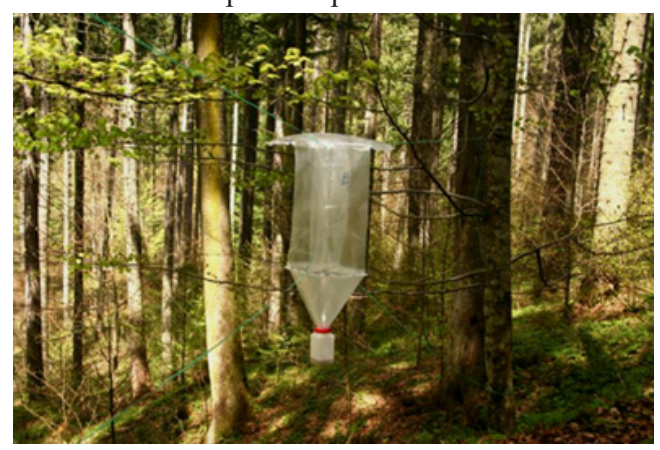

Figure 2 The flight interception trap positioned within the sampling plot in Voievodeasa. 
The following documents reinforce the legal status of saproxylic species found in nature reserve: the Directive of European Council no. 92/43 from 21.05.1992, aiming the conservation of natural habitats, of wild flora and fauna amended by the Directive 97/62/EC from 27.10.1997; the extraordinary ordinance no. 57 from June 20th, 2007, emitted by the Romanian Government regarding the protected areas, conservation of natural habitats, wild flora and fauna followed by the ordinance reinforcement Law 49/2011.

\section{Composition and abundance- dominance structure of the saproxylic beetles' community}

The analysis of window traps captures, after separation of species pertaining to order Coleoptera and more specifically to saproxylic species was focused on species richness, diversity and identification of influential species using several metrics.

A primary characterization of the saproxylic beetles' community used abundance, constancy, dominance and the synthetic Dzuba index as traditional community descriptors (Engelmann 1978, Stugren 1982). The classical approach in the characterization of communities, centred on the idea that species are not equally represented and distributed, is strictly exploratory and not necessarily explanatory. However, it gives a primary account on community structure. Supplemental information, annex 1 provides the full definition and description of the indices. Sampling provides abundance scores, used to estimate how species partition the niche space, being at the same time, an important structural feature that shows invariance (Magurran 2004, 2005). The more formal analysis modelled the abundances of saproxylic beetles intercepted at different dates and the total catch, to fit one of the most frequently employed abundance models (Fisher's logarithmic series, lognormal distribution, broken-stick model, geometric model). The approach is based on the assumption that all species within community are equal in terms of their roles (Magurran 2004).

As in the case of species, the information conveyed by the family rank is useful in diversity and community structure analysis: we constructed the families' abundance classes plot using log transformed abundance data to depict the ranking of families according to numbers of intercepted specimens pertaining to those beetle families.

Principal Components Analysis addressed the relationship between the traditional community descriptors in the discrimination of species groups. The variance-covariance matrix was constructed based on the initial species and community descriptors' scores (abundance, dominance, constancy and ecological significance). The data were log-transformed prior to the construction of variance-covariance matrix. Row-wise bootstrapping with 1000 replications was carried out to obtain the $95 \%$ confidence intervals of the calculated eigenvalues. Further analysis of correlations among indices was performed through multivariate regression holding abundance as independent variable. Sampling strategy, restricted to adult stage of the saproxylic beetles conveys information on the phenology of the species but also on community composition.

Non-Metric Multidimensional Scaling NMDS (Shepard 1966) was performed on abundance data gathered at different sampling dates across the vegetation season to assess the similarities in species composition related to phenological changes (we used Bray-Curtis metric as similarity measure). The distance among objects in the NMDS ordination space corresponded to their similarity distance and iterations stopped when minimum stress value was reached. 


\section{Species richness and diversity estimators}

Taxonomic diversity as structural community descriptor was estimated using several indices with different emphasis on rarity and commonness (Magurran 2004) integrating the information on species richness and abundances at different spatial or temporal scales. The alpha diversity analysis was performed on the aggregated saproxylic beetle community and separately, on three of its guilds, xylophagous, mycetophagous and predatory beetles. The metrics were also applied to samples containing the intercepted beetles at different sampling dates across the vegetation season.

Species richness: the simple count of species in a sample is usually an underestimate of the true number of species thus we analysed the traps content using as a key metric Chao 1 index, considered the simplest nonparametric, sample-based species richness estimator (Chao 1984, Chao \& Shen 2004). It augments the number of the observed species by a term that depends on the number of singletons (species represented by only a single individual) and doubletons (species represented by exactly two individuals) in the sample.

$$
\mathrm{S}_{\text {est }}=\mathrm{S}_{\text {obs }}+\frac{\mathrm{a}^{2}}{2 \mathrm{~b}}
$$

where $S_{\text {est }}$ stands for the estimated species richness, $\mathrm{S}_{\mathrm{obs}}$ represents the observed or sampled species richness, a is the number of singletons and $\mathrm{b}$ is the number of doubletons. The index is intuitive and performs just as well as other more complex asymptotic estimators (Gotelli \& Chao 2013).

The estimator is the best in the case of species inventories limited by available time and resources (Basualdo 2011). The calculation of the Spearman correlation coefficient between the estimated, extrapolated and the observed richness of intercepted saproxylic beetles at different sampling dates was performed to establish the sampling coverage.

Rarefaction curves: the interpolation of species richness based on abundance data and the estimation of the completeness of the inventory are usually based on rarefaction curves (Hurlbert 1971, Gotelli \& Colwell 2001) which are constructed as the standardization of samples to a common number of individuals is performed. The abundance of a larger sample is generally rarefied to the total abundance of the smaller sample to determine species richness. We considered as distinct samples the cumulated catches in window traps across the vegetation season beginning with June and finishing date in September. The curve tends, as the number of samples increases, to flatten out to an asymptote that shows the true species richness of the community under study. We also constructed the rarefaction curve accounting for the variation of intercepted saproxylic beetle numbers across different dates during the sampling interval.

The graphical depiction of ordered species relative abundances on a log scale, the rankabundance curve (RAC) is an exploratory tool for diversity analysis first introduced by MacArthur (1957) and Whittaker (1965) and used for the visualization of the community structure changes. The species are ranked according to their abundances, the obtained curve conveying information on species richness together with species evenness. The slope of the line fitting the RAC, standing also for species richness model (linear, log series or geometric relationship), reflects evenness. A steep gradient indicates low evenness and a shallow gradient corresponds to high evenness, as species abundances are similar. RAC changes in response to community changes reflected in evenness, species gain, species loss and species re-ordering (Avolio et al. 2015). We constructed RACs for the intercepted saproxylic beetles at each sampling date and corresponding to aggregated samples to visualize species richness and evenness 
changing with time according to species adult stage phenology, a more intuitive approach compared to diversity indices.

Diversity indices: Diversity is a multidimensional concept incorporating species richness and abundance summarized under a number called diversity index. These composite indices convey additional information moving from the context of species count that gives same weight to rare and abundant species (Chao et al. 2014).

Shannon (1948) entropy is the most popular non-parametric biodiversity estimator, the result expressed in logarithmic counts of information. The index is sensitive to rare species and sampling intensity.

Simpson's quadratic diversity index (1949) was devised initially as a metric expressing the dominance (D), measuring the probability of a two randomly extracted individuals to belong to two different species, it increases as diversity decreases making the interpretation of the result difficult. Therefore, the transformed 1/D and 1-D indices (also named Gini-Simpson index) are more intuitive making the indices to increase as diversity increases (Magurran 2004). We employed Simpson D and 1-D indices, both being sensitive to dominant species.

Berger-Parker (1970) proposed a simple metric that reports the proportional abundance of the most abundant species of a sample, has an analytical relationship with geometric series (May 1975) and is sensitive only to the most abundant species.

Evenness represents the degree to which individuals split among species, with low values indicating the dominance of one or few species. We employed the metric derived from Shannon's index (Morris et al. 2014).

As these indices are sensitive differently to abundant/dominant and rare species, they address different aspects of diversity. To make the results interpretable, the solution is to use one-parameter index family that allows the characterization of species assemblage by the diversity profile instead of a single value (Patil \& Taillie 1979, Tóthmérész \& Magura 2005). The one-parameter index family we used was Rényi's generalized entropy (Rényi 1961), introduced in ecology by Hill (1973) who considered that standard diversity indices (Jost 2007) were points in a diversity continuum defined by a single equation. Each member of the Rényi family of indices is defined by a scale parameter alpha (or $\mathrm{q}$ in the original paper of Hill).

$$
{ }_{\text {Hill }}^{\mathrm{q}} \mathrm{D}=\left(\sum_{\mathrm{i}=1}^{\mathrm{s}} \mathrm{p}_{1}^{\mathrm{q}}\right)^{1 /(1-\mathrm{q})}
$$

D stands for numbers equivalent or effective number of species (Jost 2007), p stands for species frequency. Every diversity index has its own effective number of species and for each $\mathrm{q}$ or alpha there is a standard diversity index. For instance, alpha $=1$ corresponds to Shannon index, Simpson's 1-D corresponds to alpha $=2$. Changing the scale parameter modifies the sensitivity of the diversity index, the change being displayed graphically by plotting the calculated diversity index against the scale parameter.

Representing the continuum graphically in diversity profiles, to different intervals of the curve correspond different diversity indices depicting the gradient from rare species to common or dominant species. However, the Hill numbers are sensitive to the number of sampled individuals and samples a condition requiring an intensive and, as much as possible, complete sampling.

All calculations and graphical representations were performed in PAST software 4.03 (Hammer et al. 2001). We also employed for the validation of the results related to species richness and biodiversity analyses the software EstimateS (version 9.1.0) (Colwell 2013). 


\section{Network analysis}

In addition to the analysis of the species richness, abundance and biodiversity pattern of saproxylic beetle community, we approached the temporal changes using the specific metrics derived from the community network. We assembled four bipartite, unweighted, and undirected networks (bipartite networks being defined by two distinct sets of nodes, links being established between sets but not within sets).

We used data on saproxylic beetles (217 species) captured in flight interception traps at different sampling dates included in a presence-absence matrix, with species on rows representing one set of the bipartite network and dates, on columns representing the other set of the bipartite network. Three bipartite subnetworks corresponding to main trophic guilds, xylophagous, mycetophagous and predatory beetles were also constructed. The analysis of the resulted networks included the following metrics, which we considered informative for the current approach: connectance, average node degree, nestedness and modularity.

Average node degree (considering the degree of a node being the number of total number of links the node has with other node of the network), in undirected bipartite networks is the number of summed links of all nodes divided by the number of nodes (Barabási 2016).

Connectivity or connectance is a communityaveraged property, considered also a niche property (Blüthgen 2010) predictive for the dynamical properties of the network (Dunne et al. 2002) and one of the first network properties to be analysed. Represents the proportion of realized links among the potential links in a network (May 1973).

Nestedness is a statistical property of the bipartite interaction data presented in matrix form and depends on the size of the matrix and fill but it is also a niche property
(Blüthgen 2010). The basic idea behind nestedness calculation is to assess the state of ordering (Ulrich 2008). It is calculated as $\mathrm{N}=(100-\mathrm{T}) / 100, \mathrm{~T}$ being the estimated matrix temperature (Bascompte et al. 2003). $\mathrm{N}$ is defined within the range $[0,1]$ where 1 corresponds to a perfectly nested network and 0 corresponds to systems where interactions occur completely at random. BINMATNEST was the employed software to estimate matrix temperature (Rodríguez-Gironés \& Santamaría 2006).

Modularity refers to community detection and is based on optimization of partitions in such a way as to separate highly connected nodes in separate units, being considered an important sub-network level property. Modularity is an intrinsic property of organisms and higher order living systems, considered to provide stability, parts being tightly integrated but exhibiting a certain degree of interdependence (Schlosser \& Wagner 2004). Analytic approaches using several categories of methods are currently employed for the calculation of modularity. The existing nodes are linked in units named modules (hubs or communities). Modular networks are locally dense and globally sparse and function as basic blocks that structure the networks (Jordano 2010, Olesen et al. 2007). Modularity represents a measure of the quality of the partitions deciding if a particular community partition is better than an alternative one (Barabási 2016). Q metric (Girvan-Newman index) measures the proportion of edges that connect the nodes within the same module using a heuristic optimization algorithm. For the current study, modularity was estimated using Louvain algorithm. Louvain method (Blondel et al. 2008) (provided by the software Pajek) estimates the modularity (Q) using a greedy optimization algorithm on the same Girvan-Newman index (2002). The modular structure of complex networks plays a critical role in their function (Newman 2003, Guimerá \& Amaral 2005) meaning that different groups 
of nodes perform different functions. We rated the nodes pertaining to different modules in three categories: hub nodes - with connections to all or almost all modules, connector nodes - which link several modules, and peripheral nodes - confined to one module. Observed modularity was tested for significance against 100 random Erdös-Rényi networks, with same connectivity and average node degree as the observed networks.

Graphical representations of the guilds' networks were generated using package bipartite in R (R Core Team 2015) and attached to annex 3. Louvain modularity was calculated in Pajek ver. 5.09 (Mrvar \& Batagelj 2016).

\section{Results}

\section{Composition and functional groups of the identified saproxylic beetles' community}

The beetles collected from the window traps in Voievodeasa forest were linked to dominant tree species: beech, fir and Norway spruce, establishing a complex assemblage of generalist and specialist consumers.

After sorting the total window traps' content, 13,554 beetles were counted, of which 7174 were identified at species and subspecies level (Supplemental information, Table 1S in annex 1). Another 6390 individuals were identified at genus and family level, and 88 individuals could not be assigned to lower-level taxa of the order Coleoptera. The remaining 13,466 individuals were assigned to 61 families. Most taxonomically diverse interval of abundances scaled to Coleoptera families (families' abundance classes plot) ranged between 11 and 50 intercepted individuals, corresponding to 16 families (Fig. 3) (Supplemental information, Table $2 \mathrm{~S}$ in annex 1), several families were represented only by singletons (Brachyceridae, Dascillidae, Dermestidae, Dryophthoridae, Rhysodidae, Trogidae and Zopheridae). High abundances were confined to few families (in the range of 700 and 5000 intercepted individuals, such as Fam. Staphylinidae, Latridiidae, Curculionidae, Ptinidae and Ciidae).
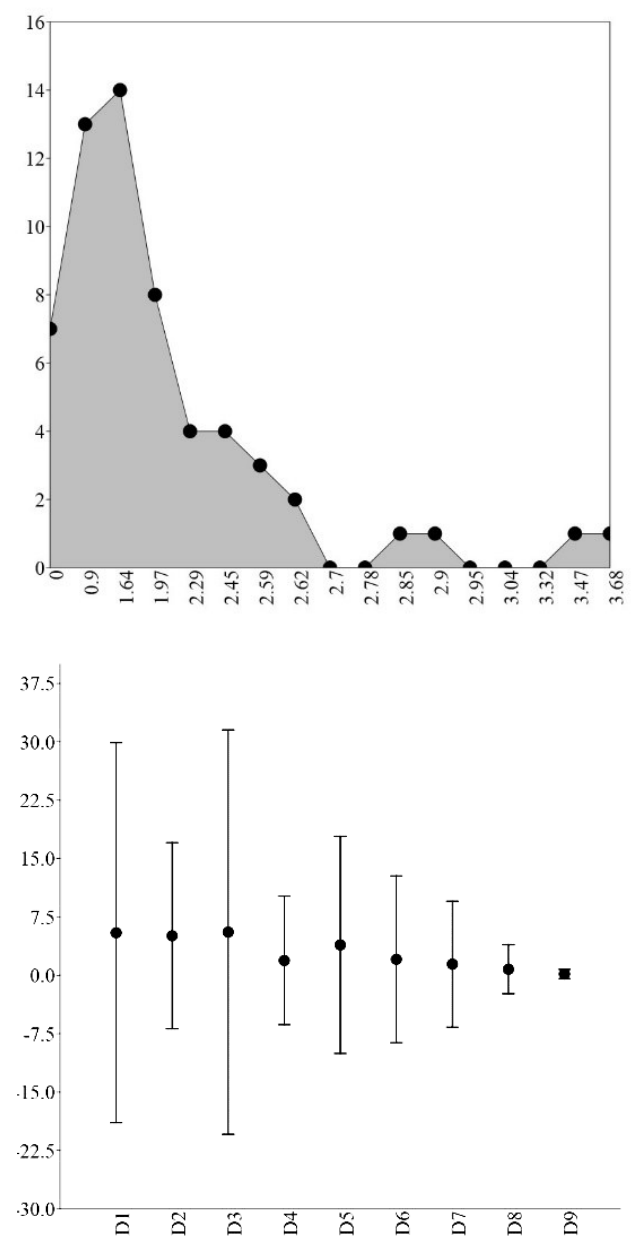

Figure 3 The abundance-classes plot (on a log scale) of the Coleoptera families intercepted in window traps in Voievodeasa Forest, during one vegetation season. Mean and standard deviation of beetle abundances corresponding to pooled samples (20 window traps) at different sampling dates. D1 - 23 May, D2 - 6 June, D3 - 20 June, D4 - 5 July, D5 - 18 July, D6 - 1 August, D7 - 16 August, D8 - 12 September, D9 - 26 September). 
7174 individuals identified at species and subspecies level were assigned to 336 species, 58 families and 218 genera (Supplemental information, Table 1S in annex 1). $65 \%$ of the identified species (217) were obligate saproxylic species (Table $3 \mathrm{~S}$ in annex 1). The non-saproxylic group included phytophagous species (rhizophagous, foliivorous and pollen consumers), species using several ephemeral food resources such as rotting mushrooms, carcasses and animal faeces, as well as species from different trophic guilds (mycetophagous, coprophagous, necrophagous, opophagous). Three species could not be assigned to any functional group in terms of utilized food resources.

The larval development of the identified saproxylic beetles takes place in different woody substrata differentiated by the degree of decomposition. Accordingly, the beetles were affiliated to the following habitat guilds: species associated to fresh dead wood (23\%), species associated with decomposing dead wood (41\%), species associated with wood decomposing fungi (34.5\%) and species confined to other types of wood depending substrata, mainly highly degraded wood hollow mould (2\%). Maximum catch corresponded to 20 June - 1205 specimens, and minimum catch to 26 September - 36 specimens, showing a wide range of interception variability across the vegetation season (Fig. 3).

The NMDS representation depicts compositional differences of saproxylic beetles' community across the sampling interval (Fig. 4). Within narrow time window (same month), the composition showed high similarity in the case of samples collected in June, and in August but high dissimilarity in July and September, the highest dissimilarity in the sampling space corresponding to samples collected in different months, in May and at the end of September.

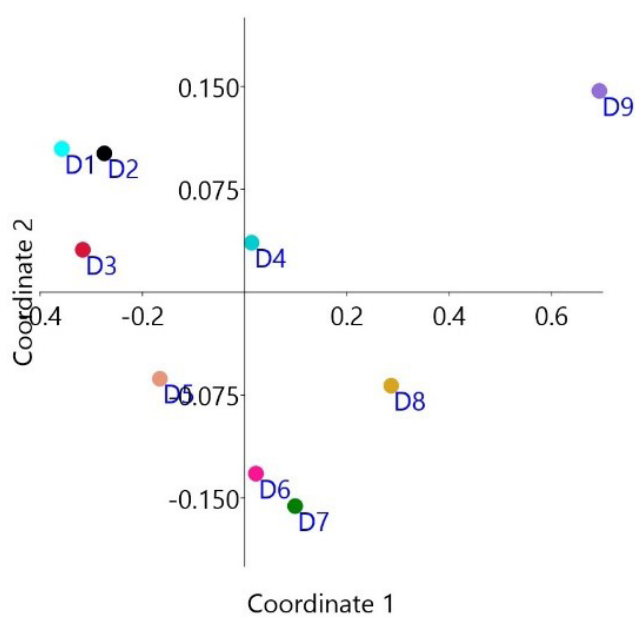

Figure 4 Non-Metric Multidimensional Scaling of the interception flight traps' catches of saproxylic beetles at different sampling dates. (similarity measure - Bray-Curtis distance, stress value $=0.06$ ).

\section{Abundance-dominance structure of the saproxylic beetle community}

The intercepted obligate saproxylic species represent a group within the larger pool of intercepted beetle assemblage, proportionally $64.5 \%$. As classical dominance-constancy indices were calculated on cumulated abundances for each species, based on captures at different dates, these indices are linked to the species' phenology during the imago stage.

Considering abundance of saproxylic Coleoptera, 16 species (7.37\%) were abundant with more than 100 captured individuals. 52 species (24\%) were relatively common (between 11 and 100 captured individuals per species) and 149 (68.6\%) were rare species (between 1 and 10 individuals per species) of which 52 species were singletons. Most abundant species in decreasing order were Ptilinus pectinicornis, Enicmus rugosus, Cis rugulosus, Taphrorychus bicolor, Enicmus testaceus, Enicmus atriceps, Hylecoetus dermestoides, Cis boletis, Abraeus granulum, Cerylon ferrugineum, Latridius 
hirtus, Mycetophagus fulvicollis, Ernoporicus fagi, Hemicoelus rufipennis, Triplax russica and Cryphalus piceae.

Abundance distribution tested on aggregated abundance data fits Fisher's log series with parameter $\alpha=44.37$, parameter $x=0.99$; significance testing resulted in $\chi^{2}=1012$ at $\mathrm{p}<0.0001$ level. The abundances at different sampling dates across the vegetation season fit also log series distribution with the exception of D2 (6 June) that fits the geometric model. Due to the small insect catches at the end of the season, the last two D8 (12 September) and D9 (26 September) were inconclusive with respect to abundance model. Log series characterize insect communities where there are many uncommon and few abundant species (Magurran 2005). In our case, the abundant species cover only $7.37 \%$ of the number of species pertaining to the pooled community. The same analysis performed on abundance data at family level resulted in the same log-series distribution, with parameter $\alpha=8.54$, parameter $\mathrm{x}=0.99$, significant for $\chi^{2}=2570$ at $\mathrm{P}<0.0001$.

The ranking of saproxylic Coleoptera according to their constancy resulted in: $25(11.5 \%)$ euconstant species, 18 (8.2\%) constant species, 39 (18\%) accessory species and $135(62.2 \%)$ accidental species (Table $2 \mathrm{~S}$ in annex 1). $75 \%$ of the traps, captured species associated to three main categories of substrates: 4 (2\%) of the captured species were associated to freshly dead wood (Dryocoetes autographus, Ernoporicus fagi, Taphrorychus bicolor, Hylecoetus dermestoides), 11 (5\%) species were associated to decomposing wood (Ptilinus pectinicornis, Abraeus granulum, Cerylon fagi, Cerylon ferrugineum, Cerylon histeroides, Ampedus erythrogonus, Denticollis linearis, and 10 (4.6\%) were associated to wood-decomposing fungi (Enicmus rugosus, Cis rugulosus, Enicmus atriceps, Cis boleti, Latridius hirtus, Stephostethus alternans, Enicmus testaceus, Mycetophagus fulvicollis, Scaphisoma agaricinum, Mycetophagus populi).
According to dominance (considering the relative abundance), 1 species $(0.4 \%$ ) was found to be eudominant (Ptilinus pectinicornis), 4 species $(1.8 \%)$ were dominant (Enicmus testaceus, Enicmus rugosus, Taphrorychus bicolor and Cis rugulosus), 7 species (3.2\%) were sub-dominant (Enicmus atriceps, Hylecoetus dermestoides, Cis boleti, Abraeus granulum, Cerylon ferrugineum, Latridius hirtus and Mycetophagus fulvicollis), 11 (5\%) species were recedent and 194 species $(89.4 \%)$ - sub-recedent.

Dzuba index provided information on ecological significance of the captured beetles as followed: 4 species $(1.8 \%)$ were scored as characteristic species for the saproxylic Coleoptera community (Ptilinus pectinicornis, Enicmus rugosus, Cis rugulosus and Taphrorychus bicolor), 72 species (33\%) were scored as accessory and 141 species (65\%) were scored as accidental.

Although the employed indices derived from species abundances were devised to reflect different qualitative aspects of the community structure, the relationships among them could be informative in their own right. Ordination performed on abundance classes, constancy, dominance and ecological significance (Dzuba index) showed that PC1 retained most of the variation, 98.04\%. All indices were highly correlated with $\mathrm{PC} 1$ and further testing using multivariate regression with dominance held as independent variable, showed high correlation among indices (Pearson's correlation coefficient $\mathrm{r}$ between 0.99 and 0.94 at $\mathrm{P}<0.0001)$. Species ranked according to these indices as rare, accidental or accessory grouped separately in the ordination space while dominant and eudominant species established another distinct group (Fig 5). The highly, positively correlated constancy and Dzuba indices are negatively correlated with abundance and dominance. 


\section{Guild structure of the saproxylic beetle community}

Habitat-wise and trophic-wise, the saproxylic beetle community consists of distinct functional groups of species, the habitat guilds and trophic guilds.

The trophic structure of the xylophagous beetles' community includes four distinct categories of consumers: xylophagous species (which consume phloem, cambium, xylem in different decomposition stages of the wood), mycetophagous species (which consume mycelia, spores and basidioma of wood decomposing fungi), predators (which prey on insects or other invertebrates dwelling the decomposing wood or wood decomposing fungi) and species which utilize other wood connected resources such as sap, detritus or scavenge on animal remains. The first two categories include comparably equal numbers of species but in terms of abundance, mycetophagous beetles are considerably more numerous (Fig. 6).

Of the 88 xylophagous beetle species, 25 were associated with fresh dead wood (corresponding to the first and second decomposition stage), 60 were associated with advanced wood decomposition and 3 species were dwellers of tree hollows detritus consisting of decomposed wood, litter and remnants of animal origin (Fig. 6).

\section{Richness of saproxylic beetles' community in Voievodeasa Forest}

Richness estimation: The sampled obligate saproxylic beetles in Voievodeasa Forest included 217 species, of which several were abundant, with more than 100 individuals captured. However, as visual inspection of the individual-based rarefaction curve (Fig. 7) shows, the number of species did not stabilize after pooling all captured individuals in all samples across the sampling period.

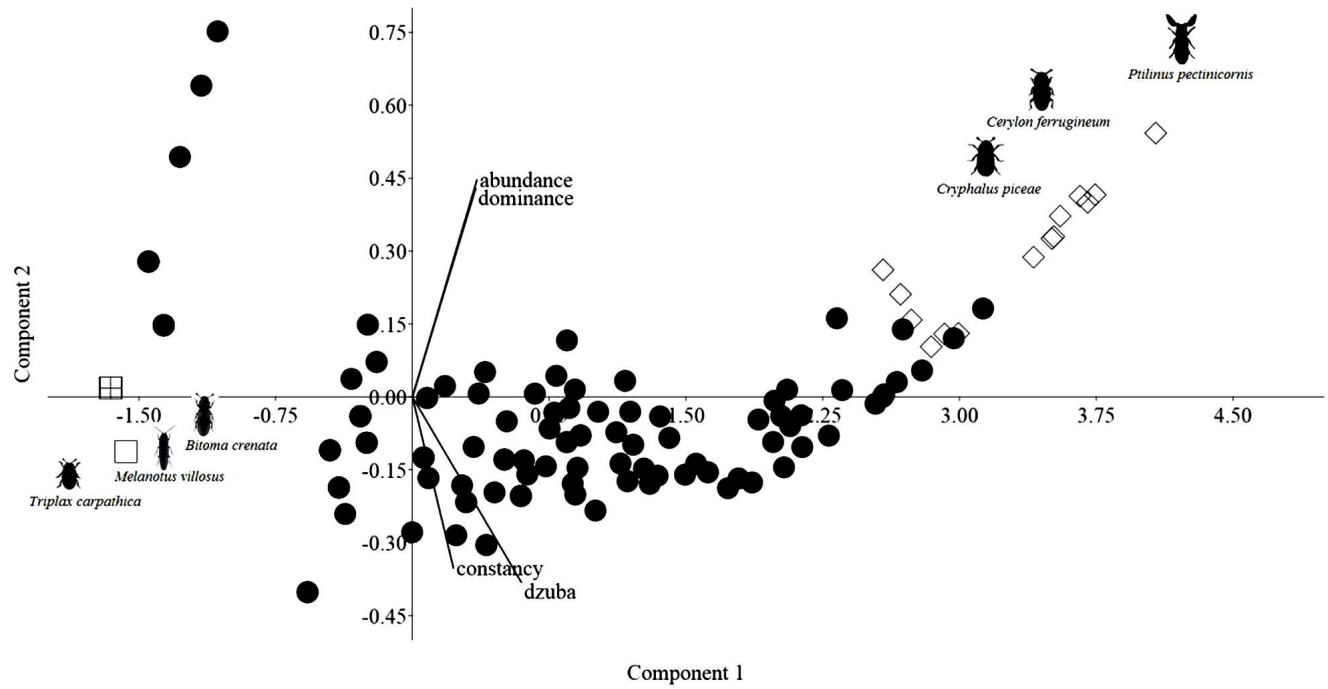

Figure 5 Relationship between the four community indices: abundance, dominance, constancy and Dzuba W - ecological significance characterizing the saproxylic beetles' community in Voievodeasa forest depicted by PCA biplot. The cluster of eudominant and dominant, constant and abundant species is represented by diamonds and the cluster of rare, singleton, accessory/accidental species is represented by squares. Due to species scores' superposition, there are few visible squares. The species occupying an intermediate position according to their abundances are figured with filled black circles. Component 1 explained $98.04 \%$ and Component $2,1.13 \%$ of the variance. 

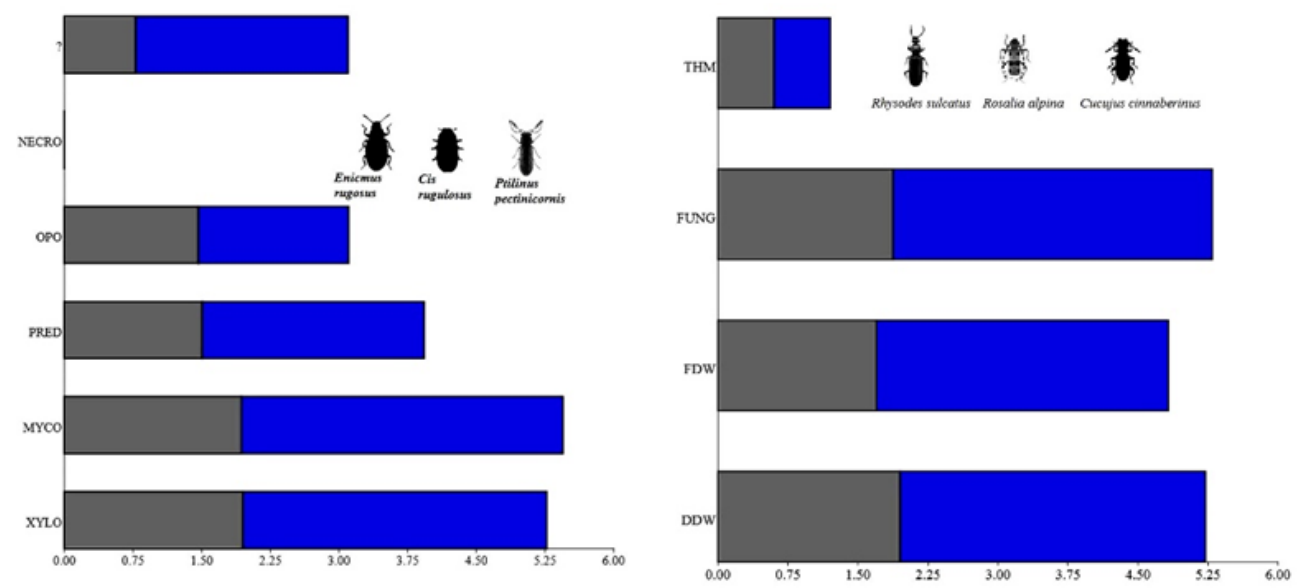

Figure 6 Bar plot representation of the abundances (blue) and number of saproxylic beetles' species (grey) according to the feeding guild (XYLO - xylophagous, MYCO - mycetophagous, PRED - predatory $\mathrm{OPO}=$ opophagous, $?=$ not determined, NECRO - necrophagous) on log transformed data. The most abundant three species: 1. Ptilinus pectinicornis, 2. Enicmus rugosus, 3. Cis rugulosus (left panel). Bar plot representation of the abundances (blue) and number of saproxylic beetles' species (grey) according to habitat guild (FDW - fresh dead wood, DDW - decomposing dead wood, FUNG - wood decomposing fungi, THM - tree hole mould) on log transformed data. Old-growth forests characteristic beetle species: Rhysodes sulcatus, Rosalia alpina, Cucujus cinnaberinus (right panel).
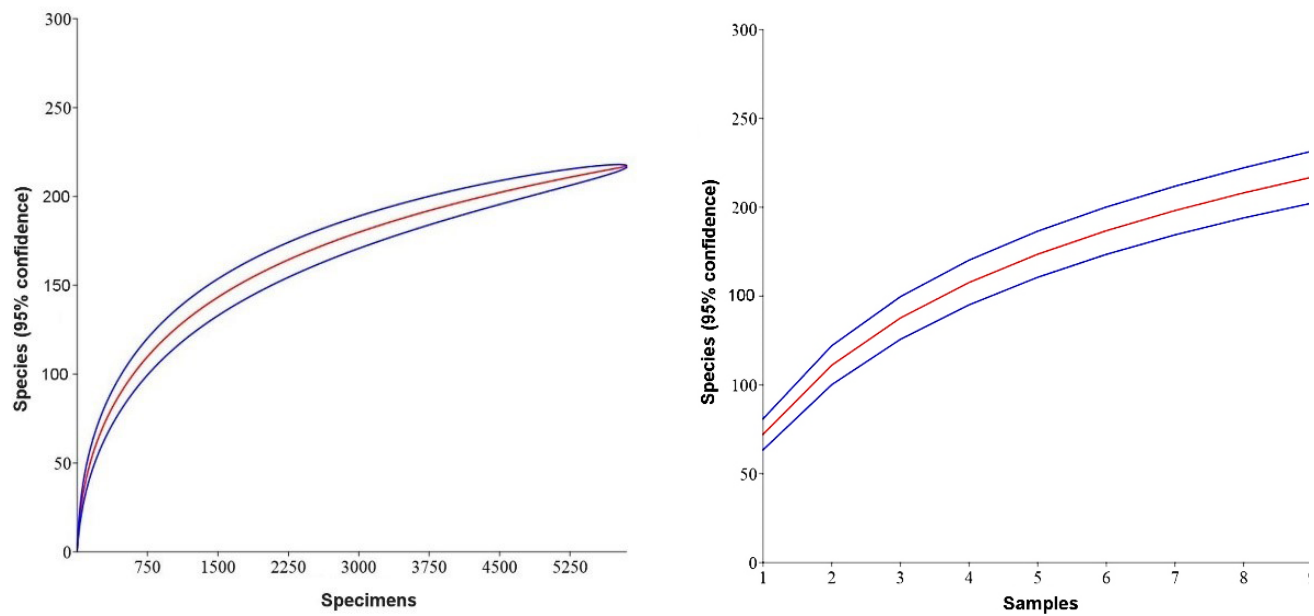

Figure 7 Individual-based rarefaction curve (left panel) and sample-based rarefaction curve performed on pooled samples (right panel) of saproxylic beetles captured in window traps in Voievodeasa Forest nature reserve. Blue lines delimit the confidence interval.

Consequently, the curve did not reach the asymptote represented by the estimated number of species under Chao 1 algorithm (see below).
According to sample-based rarefaction, the smallest rarefied sample should contain $72.22 \pm 8.89$ species, a number reached 

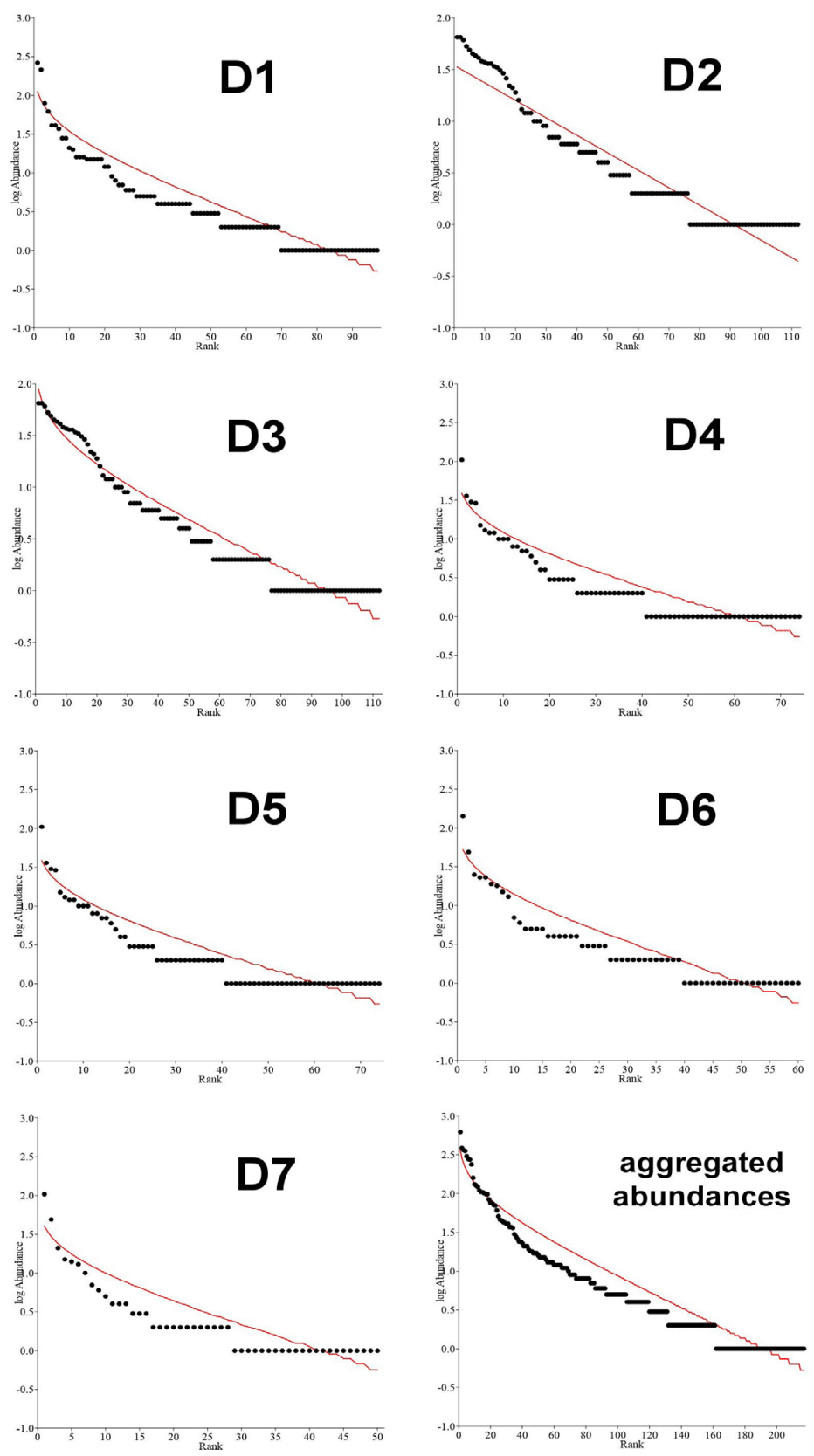

Figure 8 Rank-abundance curves and abundance distribution curves (red) of saproxylic beetles caught in flight interception traps at Voievodeasa Forest nature reserve, at different sampling dates across the season and corresponding also to the pooled catches. The last D8 and D9 sampling dates were excluded due to the small number of the intercepted beetles. The abundance distributions fit the log series model with the exception of D2 that fits the geometric model (considering individualbased rarefaction) when the sample contained 291 specimens. From this perspective, the smallest observed sample obtained at the end of September (D9) containing only 36 specimens from 20 species, was below the smallest rarefied sample.

A rarefied sample of 31 individuals would include $20.44 \pm 2.47$ species

The average Chao 1 estimate for species richness (after 100 randomizations) was $266.67 \pm 17.5$ while the number of the observed species was 217 representing 81.53\% cover of actual richness compared to the estimated richness. The trend was similar across all sampling dates, highest difference between expected and actual number of intercepted species being observed in (D8)12 September sample $(56.89 \%$ cover $)$ while the lowest difference and highest cover corresponded to (D5)18 July (87.83\%). The observed and the estimated species richness correlated strongly, Spearman's correlation coefficient $r=0.99$ confirming the consistent sampling effort.

The rank-abundance curves (RAC) constructed 
on aggregated catches and catches of saproxylic beetles at different sampling dates across the season showed variation in terms of species richness and evenness (Fig. 8). The steep gradient of the slopes indicated low Shannon's evenness confirmed by the calculations (Table $4 \mathrm{~S}$ in annex 2 and Fig. 8) as in aggregated abundances and in D1, while shallow gradient of the slope indicated higher evenness, as in D5 and D6.

The re-ordering of species ranks in time sequence was one of the most obvious trends in saproxylic beetles' community structure. For instance, Hylecoetus dermestoides occupied the first rank in D1 but in D2 it already occupied the 24th rank and disappeared during the subsequent dates. Ptilinus pecticornis held the first rank in D3, D4 and D5, being dominant during these time windows due to its longer adult stage. Cis rugulosus, another common species occupied the first rank in D6 and D7. These examples suggest that numerical dominance of species is not constant and depends strongly on species phenology.

The biodiversity analysis performed on pooled samples at each date and also on aggregated samples and dates showed that the employed indices varied in similar manner as the number of species and abundances varied across the time sequence (Supplemental information table $4 \mathrm{~S}$ in annex 2). The diversity profile (Fig. 9) shows that the aggregated saproxylic community is highly diverse and highly uneven, with rich representation of rare species. By contrast, the sampled community at the end of the vegetation season (D8 and D9) was consistently even. The highest diversity corresponding to dominant species (for $\alpha=1$ and $\alpha=2$ ) characterizes the aggregated community and samples D2 and D6. The community sampled in D2 presented the highest expressed dominance, the second numerically dominated by few species being the pooled saproxylic beetle community (corresponding to BergerParker index). Larger values of $\alpha$ put more weight on common species, while values close to 0 are estimates of species richness.
We consider that the calculated indices and the diversity profile give a correct estimation of the diversity of the local saproxylic beetles' community since the observed richness was close to the estimated.

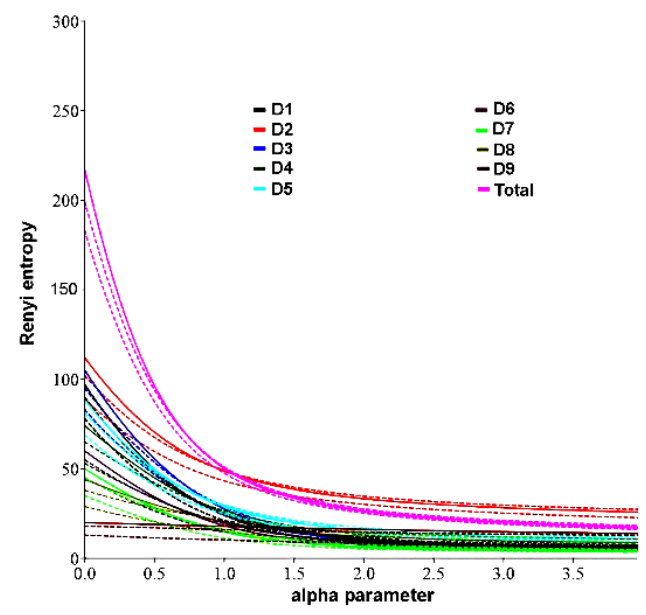

Figure 9 Diversity profiles of aggregated saproxylic beetles' community and species assemblages at different sampling dates in Voievodeasa forest. Different sampling dates are indicated by different coloured lines, magenta line corresponding to pooled data. Confidence limits are depicted with interrupted lines. Alpha parameter: $\alpha=0$ corresponds to species richness, $\alpha=1$ corresponds to Shannon index, $\alpha=2$ corresponds to GiniSimpson index, $\alpha>2$ corresponds to Berger-Parker index. The steep gradient indicates low evenness.

Shannon index, putting more weight on species richness emphasized that the saproxylic beetles' community was highly diverse (Table 4 in annex 2) but also highly uneven considering how abundances are partitioned among species. As Margalef (1972) stated, the value of Shannon biodiversity index obtained from empirical data generally is situated between 1.5 and 3.5, rarely over 4, our results demonstrating high biodiversity of the saproxylic beetles' community, with highest value corresponding to cumulated catches and 
second highest, corresponding to the sample collected on 6th June. The estimated evenness (0.23) described a community with several dominant species in terms of abundances and many rare species, with low abundances. The low number of species (20) and their low abundances (36) biases high evenness corresponding to sample collected on 26th September.

\section{Network analysis}

The bipartite, qualitative and unweighted networks of the main trophic guilds, xylophagous, mycetophagous and predatory species as well as the aggregated saproxylic beetles' community network, intercepted by window traps across the sampling period show a common trend: high connectivity and high nestedness (significant over 1000 simulations) (Table 2).

Highest number of links per species (average node degree) corresponded to mycophagous guild which displayed also the highest connectance, while the highest nestedness corresponded to the predatory guild. Another topological characteristic is the modular structure of all analysed networks with the exception of mycophagous beetles' network, confirmed by Louvain algorithm and tested against 100 random Erdös-Rényi networks, with same connectivity and average node degree as the observed networks. Modules merged the nodes representing the species centred on the different sampling dates, in several situations one module merging two consecutive sampling dates, thus covering a time window of a month. The network of the aggregated saproxylic community displayed six modules, three of them resulting from pooling two consecutive sampling dates. The number of peripheral nodes, confined only to one module decreased from 35 nodes at the beginning of the sampling period to zero nodesat the end of the sampling period corresponding to species with short adult stage. The same trend was observed in the networks corresponding to predatory and xylophagous guilds, each with five modules. The hub nodes corresponding to species with long adult stage, both abundant or with few intercepted individuals during the vegetation season increased from the first four sampling data (from 0 ) to highest number at the end of this period ( 9 hub nodes at the end of September in the case of aggregated saproxylic community). Among the species corresponding to hub nodes, species that were intercepted across the

Table 2 Network metrics calculated for the trophic guilds and aggregated saproxylic beetles' community identified in Voievodeasa Forest nature reserve.

\begin{tabular}{lcccc}
\hline \multicolumn{1}{c}{ Metric } & $\begin{array}{c}\text { Xylophagous } \\
\text { beetles }\end{array}$ & $\begin{array}{c}\text { Mycophagous } \\
\text { beetles }\end{array}$ & Predatory beetles & $\begin{array}{c}\text { Aggregated } \\
\text { saproxylic }\end{array}$ \\
\hline Connectivity & 0.27 & 0.39 & 0.24 & 0.33 \\
Average degree & 4.50 & 6.59 & 3.65 & 5.75 \\
Nestedness & 0.84 & 0.73 & 0.86 & 0.79 \\
& $\left(\mathrm{p}_{3}=0.001\right)^{* * *}$ & $\left(\mathrm{p}_{3}=0.001\right)^{* *}$ & $\left(\mathrm{p}_{3}=0.001\right)^{* * *}$ & $\left(\mathrm{p}_{3}=0.001\right)$ \\
Modularity (M) & 0.32 & $\mathrm{NS}$ & 0.38 & 0.26 \\
& $(6$ modules $)$ & & $(5$ modules $)$ & $(6$ modules $)$ \\
Number of nodes & 96 & 118 & 58 & 217 \\
Number of links & 216 & 369 & 106 & 650 \\
\hline
\end{tabular}


entire sampling period were Cis boleti, Enicmus rugosus, Ernoporicus fagi, Agathidium discoideum, Melanotus castanipes, Cryphalus piceae, Octotemnus glabricus, Anisotoma humeralis, etc. The trend was consistently the same in the case of the subnetworks. The majority of nodes in all networks played the role of connectors meaning that species could be retrieved in more than one occasion but not in all nine dates. The topologies of the networks were determined by shifts in species composition and species richness. As Chao 1 index and rarefaction curves showed, there was a good sampling coverage and good species resolution. Therefore, we assumed that the analysed networks depicted closely the actual community composition and the networks reflected closely the composition shifts across the seasonal time window.

The graphical representation of the networks is attached to annex 3 in supplemental information.

\section{Conservation and legal status of the identified saproxylic beetles}

From 217 identified species of obligate saproxylic beetles, 62 are included in the European Red List of Saproxylic Coleoptera (Table 2S in annex 1) of which 51 are of least concern, 4 are data deficient, 5 are near threatened (Protaetia fieberi, Cucujus cinnaberinus, Crepidophorus mutilatus, Ceruchus chrysomelinus and Prostomis mandibularis), one is vulnerable, (Ischnodes sanguinolentus) and one is endangered (Rhysodes sulcatus) (Table 3). All these species were represented by one or maximum three sampled individuals, intercepted once or at maximum in three different sampling dates, being classified as rare.

Two of the identified saproxylic species, included in the European Red List are also new for Romanian fauna: Denticollis interpositus Roubal, 1941 and Hylis procerulus (Mannerheim 1823).
Table 3 Relict saproxylic beetles indicating old-growth forests, identified in Voievodeasa Forest nature reserve and their conservation status.

\begin{tabular}{clcc}
\hline No. & \multicolumn{1}{c}{ Species } & $\begin{array}{c}\text { Relict } \\
\text { category }\end{array}$ & Endangerment \\
\hline 1. & Rhysodes sulcatus & 1 & $\mathrm{EN}$ \\
2. & Protaetia fieberi & - & $\mathrm{NT}$ \\
3. & Rosalia alpina & 2 & $\mathrm{LC}$ \\
4. & Cucujus cinnaberinus & - & $\mathrm{NT}$ \\
5. & Ampedus elegantulus & 2 & $\mathrm{LC}$ \\
6. & Crepidophorus mutilatus & 2 & $\mathrm{NT}$ \\
7. & Ischnodes sanguinicollis & 2 & $\mathrm{VU}$ \\
8. & Triplax elongata & 1 & $\mathrm{LC}$ \\
9. & Ceruchus chrysomelinus & 2 & $\mathrm{NT}$ \\
10. & Mycetophagus ater & 2 & $\mathrm{DD}$ \\
11. & Prostomis mandibularis & 2 & $\mathrm{NT}$ \\
\hline
\end{tabular}

Zaharia (2006) mentioned the presence in Romania of $D$. linearis and D. rubens. Concerning D. rubens, the species has not been found over the last 100 years while on $H$. procerulus there were no previous data to mention the presence in Romania of this species.

Rosalia alpina and Ceruchus chrysomelinus are not currently considered threatened according to the European Red List EU27. However, for Carpathian area, these species reached the status of endangered/ vulnerable (Witkowski et al. 2003).

Rosalia alpina and Cucujus cinnaberinus are included in the Red List EU 
27 and in the annex II of EU Directive 92/43 from 05.21.1995 (animal and plant species of community interest whose conservation requires the designation of special areas of conservation). Rosalia alpina is a priority species for conservation efforts, being included among vulnerable species in the world and of least concern in Europe (IUCN classification) considered of mostly unfavourable status of conservation across Europe (eunis.eea.europe. eu/species/313).

\section{Discussion}

According to Teodosiu (2014b), the forest area where we installed the flight interception traps (management unit 5A) showed an average density of 27 snags/ha (higher density of 60/ ha being found in the contiguous management unit 5B) and an average density of $35 \mathrm{logs} / \mathrm{ha}$. The average snag volume of $6.9 \mathrm{~m}^{3} / \mathrm{ha}$ was low if compared to reported figures for unmanaged beech forests in other parts of Europe as for example Sweden with $39 \mathrm{~m}^{3} / \mathrm{ha}$ (Brunet \& Isacsson 2009). It is generally accepted that the saproxylic beetles' diversity is linked to the amount and category of coarse woody debris (Speigh 1989, Grove 2002), being represented by several habitat and feeding guilds (Speigh 1989, Schmidl \& Busler 2004). The results have shown that the richness and diversity of intercepted saproxylic beetles as well as guild structure were high and complex in Voievodeasa forest.

Window traps are activity traps, therefore, species with low activity or rarely caught in interception traps are not detected; for instance, tree hollow specialists with low dispersal abilities are omitted from this type of sampling technique (Hedin et al. 2007). Species with short adult stage phenophase may also remain undetected. Consequently, the composition of window traps is a raw estimate of the actual composition of saproxylic beetle community. The habitat-guilds of dead decomposing wood, freshly cut wood, fungi-dwelling beetles are almost equally represented suggesting that the complex food webs responsible for wood decomposition and nutrient cycling in the forest are functioning in the studied area, an important observation in the context of the growing concern about the decline of saproxylic organisms in managed forests (Stockland et al. 2012).

The relatively low content of dead wood in Voievodeasa forest nature reserve of less than $30 \mathrm{t} / \mathrm{ha}$ according to previously published observations (Teodosiu 2014b) and following the classification of Lachat et al. (2012), was reflected particularly in the low abundances of species considered old-growth forests' relicts. However, the species richness of saproxylic beetles affiliated to different trophic groups and levels of commonness and their sampling abundances were considerable.

\section{The composition of the saproxylic beetle community}

Generally, the family level conveys a small amount of information on community structure. However, at high resolution of species registration due to intensive and extensive sampling of saproxylic beetles, successional trends emerge and follow the same pattern as the higher taxonomic resolution of species level. Families (and sub-families according to the case) display a trend from early successional colonizers of trees, first stage of wood decomposition with dominating Scolytinae, Cerambycidae and Buprestidae to late decomposition stages dominated by Ptiliidae, Elateridae and Lucanidae (Dajoz 2000, Parisi et al. 2018). Most speciose families in our catches harbor species that are colonists of various wood decay stages, from first stage such as Curculionidae to late stages colonists such as Ptiliidae. Highest catches corresponding to Staphylinidae (4839 individuals) relate to late decay stage in beech and to all decay stages of fir (Dajoz 2000).

In terms of species richness, our results 
are comparable with other similar studies developed in Europe in similar or close types of forest ecosystem. For instance, the reported number of saproxylic beetles identified in beech forest strict reserves in Germany was 177 (Müller et al. 2008).

The most diversified saproxylic guild included xylophagous species associated with advanced stages of wood decomposition characterized by their special substrate demands and, by consequence, their presence signals the high degree of naturalness of the investigated forest. Taking into consideration the relatively low content in coarse woody debris, the presence of Rhysodes sulcatus, a habitat specialist colonizing only lying dead wood with diameters over $60 \mathrm{~cm}$, with high water content and in a state of advanced decomposition (Kostanjsek et al. 2018) is remarkable. Possible explanation resides in the fact that the survival of relict insect species was determined by the presence of old forest stands within the reserve. These were the first generation of cultivated forests in an area of natural forests without anthropogenic interventions until the end of 19th century (Ichim 1988).

According to Schmidl and Bussler (2004), this category includes Rhysodes sulcatus, Rosalia alpina, Leptura aurulenta, Cucujus cinnaberinus, Ampedus elegantulus, Denticollis rubens, Hylis procerulus, Ceruchus chrysomelinus, Melandrya barbata and Prostomis mandibularis. The wood hollow detritus is colonized by few beetle species (Protaetia fieberi, Ischnodes sanguinicollis, Prionychus ater) represented by singletons in our trap captures. The first two species indicate high degree of forests' naturalness. Among the identified species are old-growth forests relics (Müller et al. 2005) such as Rhysodes sulcatus, Rosalia alpina, Cucujus cinnaberinus, Ampedus elegantulus, Ischnodes sanguinicollis and Ceruchus chrysomelinus.

Not only dead wood contributes to saproxylic insects' diversity but also wood inhabiting fungi. Our results showed that mycophagous species richness was close to xylophagous beetles' guild richness. Bässler et al. (2010) has shown that old-growth forests support more red-listed fungal species than managed forests. Consequently, mycophagous beetles, dependent on wood inhabiting fungi are more diverse in high naturalness forests.

The group of mycetophagous beetles displays a large spectrum of substrate dependent and food type demands. The beetles from Scolitynae colonize the fresh dead wood inoculating it with ambrosia fungi that develop as food resources for the larvae and young beetles. Therefore, these species would pertain to the more appropriate group, the xylomycophagous beetles (Bouget et al. 2005). For instance, Trypodendrondron domesticum and $T$. lineatum cultivate the fungus Ambrosiella ferruginea (Mathiesen-Käärik) L.R. Batra. Species of Xyleborus develop a mutualistic interaction with Ambrosiella hartigii L.R. Batra and X. saxesenii associates with Ambrosiella sulphurea L.R. Batra (Kirisits 2007). Another example is Xylosandrus germanus who associates with Ambrosiella grosmanniae C. Mayers, McNew \& T.C. Harr. (Mayers et al. 2015). The same type of interaction was documented in Hylecoetus dermestoides (Fam. Lymexylidae) associating with Endomyces hylecoeti Neger (Schwenke 1974).

The majority of mycetophagous insects are associated with highly decomposed dead-wood and the carpophores of wooddecomposing fungi and in relation to fungus identity are generalists or specialists (Jonsell et al. 2001). Approximately all species from the family Ciidae and several species from Anobiidae, Erotylidae, Melandryidae, Nitidulidae and Trogositidae are dwellers of wood fungi included in the order Polyporales (Basydiomycota, Agarycomycetidae). Thus, beetles captured in flight interception traps, in Voievodeasa Forest, Cis boleti, C. micans, Octotemnus glabriculus are encountered 
in carpophores of Trametes spp., while Cis jaquemarti and Dorcatoma robusta - in fruit bodies of Fomes fomentarius (Siitonen \& Jonsson 2012). The beetle Pteryngium crenatum is feeding on basidiospores of Fomitopsis pinicola (Nikitsky \& Schiegel 2004). The saproxylic beetles inhabiting wood decomposing fungi of ord. Polyporales are not only host specific but also habitat-specific. For instance, $O$. glabriculus and $C$. boleti colonize the basidioma of Trametes spp. in closed stands while Sulcacis affinis and Cis hispidus are colonizing the basidioma emerging from stumps in clearcuts (Komonen \& Kouki 2005). Other saproxylic beetles are colonizing the soft Agaricales basidioma, this being the case of Triplax aenea (Erotylidae) and Cyllodes ater (Nitidulidae) feeding on Pleurotus spp.

Numerous species of mycetophagous beetles are feeding on mycelia developing under the bark of dead trees or in highly decomposed wood. Examples are Cerylon spp. and other species from Latridiidae, Leiodidae, Mycetophagidae, etc. The narrow host specialization is related also to hyphal structure and the type of wood decay produced by the fungi (Schigel 2012).

Within the trophic group of mycetophagous beetles are placed intercepted species considered naturalness indicators such as: Abdera affinis, Mycetophagus ater, $M$. fulvicollis, M. populi, Mycetina cruciata, Triplax aenea, T. elongata, T. scutellaris, Peltis ferruginea and Thymalus limbatus. Two species, T. elongata and $M$. ater are included among relicts of old-growth forests (Müller et al. 2005).

Predatory species follow their preys in all wood decomposition stages such as Cucujidae, Cleridae and Staphylinidae beetles (Dajoz 2000). Predatory saproxylic beetles are found in most of cases in dead, decomposing wood but several species are preying on other saproxylic insects developing in fresh dead wood. In this category, most of the predatory insects are targeting scolytin beetles (Leptophloeus alternans, Rhizophagus spp., Pityophagus ferrugineus, Rabocerus foveolatus, Salpingus planirostris, S. ruficollis, Nemozoma elongatum). Other consumers of Scolytinae beetles are Corticeus unicolor (fam. Tenebrionidae) and Ipidia binotata (fam. Nitidulidae). These species feed on other species' larvae colonizing dead wood following Scolytinae. This is the reason for considering the species as associated with decomposing dead wood rather than with fresh dead wood. Most of the predatory beetles associated with decomposing dead wood are during their larval stages exclusively entomophagous, but species of Lycidae are consuming wood too during their larval stages. Because fresh dead wood and the associated xylophagous beetles are frequent in all types of forests, it is considered that the predatory beetles preying in these substrates are not endangered. On the contrary, the species associated with highly decomposed wood are rare and many are considered relicts of old-growth forests (Müller et al. 2005). Examples of intercepted relict beetles are Pediacus dermestoides, Crepidophorus mutilatus, Benibotarus taygetanus and Ipidia binotata. Erodites cosnardi on the other hand, indicates high forest naturalness.

The practical constraints of forest management led eventually to simplified biological communities across European forest ecosystems (Parisi et al. 2018), translated in the loss of species diversity in previously hyper-diverse saproxylic communities. The majority of insect species associated with fresh dead wood and with more advanced stages of decomposition are generally considered by practitioners as harmful for commercial forests. Nevertheless, from ecological perspective, these are initiating the decomposition succession and are facilitating the subsequent colonization of wood by saproxylic insects. This key functional group is consistently more diversified in forests characterized by high degree of naturalness. Fresh dead wood is a type of substrate frequently encountered in 
commercial forests and xylophagous insects associated with this substrate are by default, not endangered. However, few individuals, classified accordingly, as rare, represented these insects in Voievodeasa forest.

The variation of the composition of saproxylic beetle community across sampling months in Voievodeasa forest as depicted by NMDS ordination followed a pattern of change occurring also at the larger time scale when variation across years was observed (Wende et al. 2017), a pattern to be considered when beetles' diversity was monitored.

Community structure revealed by the abundance data showed that the common pattern for insect communities is the logseries distribution. As model predicts, the greatest number of species will be in the lowest abundance class, which our empirical data confirmed. The long tail of the distribution consists of rare, infrequent and/or species with short adult phenophase. The log series model implies that the abundance distribution is influenced by few factors to shape the species assemblages (Magurran 2008) and it must be assumed that the factors are linked to the habitat and food resource the beetles utilize, dead wood, a less stable environment sensu Volkov et al. (2005). Locally rare species may be common in other areas of their areal (Longino et al. 2002) but it is also true that there are species, which establish local sparse populations. Extensive sampling over long periods may also determine the change of species abundance ranking and it must be kept in mind that our observations extended within the time window of one vegetation season, using exclusively, the flight interception traps. Our observations showed in this context that abundance ranking changed during the sampling period in accordance with the phenology of the adult stage of the intercepted saproxylic beetles.

PCA and regression analysis showed that other descriptive, traditional indices derived from abundance were useful tools for the exploratory characterization of the saproxylic beetles' community. The ordination of species according to employed indices (abundance, constancy, Dzuba index and dominance) produced clusters depicting different importance positions of the species in the sampling space, with few abundant and dominant species, several species of intermediary abundances and numerous rare species. However, the concept is relative and depends on the scale of observation and on the manner the community has been delineated (Magurran 2008).

\section{Richness and diversity}

The observed richness corresponds to the case of hyperdiverse communities (as microbial communities in soil or forest insect communities), where sampling never leads to the stabilization of species richness under a realistic sampling scheme (Coddington et al. 2009). The Chao 1 index is sensitive to hard-to-detect or rare species (Gotelli \& Chao 2013) and the sampling design based on the interception of the adult insects probably have failed to include more elusive species, either with primarily terrestrial locomotion, or with short adult stage.

It was previously shown that site history affected the saproxylic beetle guilds (Gossner et al. 2008), Voievodeasa forest being a relatively recently established nature reserve, with a previous management history, the dead wood quantity was rather modest. Rarity deserves a special comment given the context of saproxylic beetles intercepted by window traps: small local populations may determine this feature (the degree of endangerment included), by sampling bias, by short adult stage phenophase, habitat specialization or endemicity (Rabinowitz 1981). Therefore, a large proportion of singletons, also partly explained by the particular sampling universe, generally characterizes sampled insect communities. The use of several 
diversity indices integrated into diversity profile confirmed that the high diversity was partitioned among few dominating, in terms of abundance species and many rare. The sampling did not exhaust the local species richness (as rarefaction curves and Chao 1 index have shown) due to the limitations of sampling protocol and the intrinsic nature of hyperdiverse insect communities. However, it represented a good approximation of the actual community composition confirmed by the high positive correlation between observed and estimated species richness.

Rank-abundance curves showed that richness and evenness varied across the sampling time sequence with species re-ordering and changes in composition. Abundant species showing numerical dominance maintained their positions within the saproxylic beetles' community for relatively short periods of time, the change in their ranking suggesting that dominance is not constant for a species. The observation comes to confirm the fact that under high naturalness condition, species of practical concern such as Trypodendron lineatum, Ips typographus and Pityogenes chalcographus are not particularly abundant and occupy the tail or an intermediate position on the rank-abundance curve in highly natural forest ecosystems.

It is worth to mention in this context the presence of the invasive species Xylosandrus germanus captured in flight interception traps, a species reported for the first time in Romania quite recently (Olenici et al. 2014), raising concerns due to its relatively rapid spread.

\section{Network analysis}

Our findings show that network properties vary due to species composition and richness. Linking species to time sequences unravel species turnover across one vegetation season, community structure being scale dependent in relation to different extents of time windows considered (Schwartz et al. 2020). There are species present for most of the vegetation season (like Cerylon ferrugineum) and species emerging and disappearing in relatively short time (as species of the family Buprestidae) or rare species, which maybe, escape trapping. Previous work of Wende et al. (2017) has shown that the composition of the saproxylic beetles' assemblages varied also between consecutive years. At smaller time scale extending in the range of several month of the vegetation season, species' composition variation links to time length of adult stage as it is reflected by the specificity of the capture method, flight interception traps. It also shows that different time windows of adult beetle's activities reflect the temporal partition of their ecological niches modelled by same resource, the dead wood considered as specific breeding habitat and/or feeding resource (directly or indirectly, through the established complex trophic web). For instance, buprestid and cerambycid beetles feed on leaves and flowers, avoiding the competition for same food resources with their immatures (Bense 1995). A different assemblage composition might emerge taking into consideration the immature life stages.

The construction of ecological networks of the saproxylic beetle assemblages, split on distinct trophic guilds linked to time at seasonal scale, allows a deeper insight into assemblages' partitions due to the emerged topologies. However, the employed metrics must be interpreted with caution. Nestedness is no longer a property reflecting the relationships between generalists or specialists (coreperipheral species) but the relationships between overlapping phenophases of long-lived adults of some species and non-overlapping species with short adulthood. Highest nestedness of predatory beetles indicate the high overlap in adults' phenologies, higher compared to their xylophagous or mycetophagous preys, also the niche overlap taking into consideration the predatory life style of their immatures. All these networks contain a mixture of overlapping and non-overlapping phenologies (Vasquez et al. 
2009). Connectivity, a basic network property, links to the same phenomenon, sequential partition of time considered as a resource. pecies with longer phenophases accumulate more links over time (Schwartz et al. 2020).

Concerning modularity in the context of time dependent networks, an important outcome of the analysis consisted in the observation that hub species extend over longer time their adulthood and peripheral species are short lived adults or probably, occasional migrants from the meta-community of saproxylic beetles. Species with short adult stage establish the within module links which decrease in numbers as vegetation season progress. At the end of the season there are few species and almost all are hub and connector species, those who establish the between modules links. These topological characteristics determine a specific time dependent network architecture.

\section{Conclusions}

The saproxylic beetle community from Voievodeasa nature reserve displays high species and family level richness facilitated by the previous status of the reserve, a former commercial forest. However, prior to the establishment of the Voievodeasa protected area, the forest already benefitted from high naturalness enhanced by the presence of species considered relics of old-growth forests (9 species), also indicators of naturalness.

According to the Red List of endangered European saproxylic beetles and endangered species from Carpathians, in Voievodeasa reserve dwell six endangered species (Rhysodes sulcatus, Ischnodes sanguinicollis, Rosalia alpina, Protaetia fieberi, Cucujus cinnaberinus and Ceruchus chrysomelinus). The endangered saproxylic beetles (considered at European level) were rare in our samples indicating low local populations. Three species are protected by law such as Rosalia alpina, Rhysodes sulcatus and Cucujus cinnaberinus.

The analysis of the local saproxylic beetle community revealed several structural traits:

- High species and family level richness, high numerical representation of the xylophagous and mycetophagous guilds.

- Variation of species composition and abundances across the sampling period with overlapping and non-overlapping phenologies of the saproxylic beetle adults.

- The abundances at species and family level follow generally the log-series distribution.

- Species richness did not reach an asymptote due to sampling limitations and the nature of saproxylic insects characterized as hyperdiverse communities.

- Numerical dominance of few species varied across the sampling period, the community being characterized by sequential species reordering.

- The high diversity was partitioned among few abundant and many rare species.

- The topology of beetles' community and of the three main trophic guilds linked to time sequences is characterized by high connectance, high nestedness and modularity.

\section{Acknowledgements}

The research was conducted in the project 'Biodiversity assessment in the protected natural areas of national interest Voievodeasa forest, Marginea forest district, and old-growth forest Loben, Moldovita forest district, as a support for the foundation of their management', financially supported by the Forest Direction Suceava. We are grateful to the staff of Forest Direction Suceava and Forest district Marginea for the support in the field work. The paper in the present form was elaborated in the project PN 19070203, financed by the Ministry of Research, Innovation and Digitalization. The authors would like to thank the two anonymous reviewers for their constructive comments on the initial version of this manuscript. 


\section{References}

Albrecht L., 1991. Die Bedeutung des toten Holzes im Wald [The importance of dead wood in the forest]. Forstwissenschaftliches Centrablatt 110(2): 106-113.

Anonymous, 2010. Amenajamentul Unității de Producție II Bercheza, Ocolul Silvic Marginea. [The management plan of the Production Unit II Bercheza, Forest District Marginea].

Assing V., Schülke M., 2011. Freude-Harde-LohseKlausnitzer - Die Käfer Mitteleuropas [The beetles of Central Europe]. Band 4. Staphylinidae I. Zweite neubearbeitete Auflage. Spektrum Akademischer Verlag, Heidelberg, $560 \mathrm{p}$.

Avolio M.L., La Pierre K.J., Houseman G.R., Koerner S.E., Grman E., Isbell F. et al., 2015. A framework for quantifying the magnitude and variability of community responses to global change drivers. Ecosphere 6(12): 280. https://doi.org/10.1890/ES15-00317.1

Barabási A-L., 2016. Network Science. Cambridge University Press. Cambridge, 475 p.

Bascompte J., Jordano P., Melián C.J., Olesen J.M., 2003. The nested assembly of plant-animal mutualistic networks. PNAS 100(16): 9383-9387. https://doi. org/10.1073/pnas.1633576100

Bässler C., Müller J., Dziock F., Brandl R., 2010. Effects of resource availability and climate on the diversity of wood-decaying fungi. Journal of Ecology 98(4): 822832. https://doi.org/10.1111/j.1365-2745.2010.01669.x

Basualdo C.V., 2011. Choosing the best non-parametric richness estimator for benthic macroinvertebrates databases. Revista de la Sociedad Entomológica Argentina 70 (1-2): 27-38.

Bense U., 1995. Longhorn beetles. Illustrated key to the Cerambycidae and Vesperidae of Europe. Margraf Verlag, Weikersheim, Germany, 512 p.

Berger W.H., Parker L.F., 1970. Diversity of planktonic foraminifera in deep-sea sediments. Science 168(3937): 1345-1347.

Blondel D.V., Guillaume J.-L., Lambiotte R., Lefebre E., 2008. Fast-unfolding of communities in large networks. Journal of Statistical Mechanics: Theory and Experiment 10: P 10008t. https://doi.org/10.1088/1742$5468 / 2008 / 10 / \mathrm{p} 10008$

Blüthgen N., 2010. Why network analysis is often disconnected from community ecology: A critique and an ecologist guide. Basic and Applied Ecology 11: 185195. https://doi.org/10.1016/j.baae.2010.01.001

Bouget C., Brustel H., Nageleisen L.-M., 2005. Nomenclature des groupes écologiques d'insectes liés au bois: synthèse et mise au point sémantique [Nomenclature of wood-inhabiting groups in forest entomology: synthesis and semantic adjustments]. Comptes Rendus Biologies 326: 936-948. https://doi. org/10.1016/j.crvi.2005.08.003

Brunet J., Isacsson G., 2009. Influence of snag characteristics on saproxylic beetle assemblages in a south Swedish beech forest. Journal of Insect Conservation 13(5): 515-528. https://doi.org/10.1007/ s10841-008-9200-3

Cálix M., Alexander K.N.A., Nieto A., Dodelin B., Soldati F., Telnov D. et al., 2018. European red list of saproxylic beetles. Brussels, Belgium: IUCN. Available at: http:// www.iucnredlist.org/initiatives/europe/publi cations

Chao A., 1984. Nonparametric estimation of the number of classes in a population. Scandinavian Journal of Statistics 11: 265-270

Chao A., Shen T.-J., 2004. Nonparametric prediction in species sampling. Journal of Agricultural, Biological and Environmental Statistics 9(3): 253-269. https://doi. org/10.1198/108571104X3262

Chao A., Gotelli N.J., Hsieh T.C., Sander E.L., Ma K.H., Colwell R.K., Ellison A.M., 2014. Rarefaction and extrapolation with Hill numbers: a framework for sampling and estimation in species diversity studies.

Ecological Monographs 84(1): 45-67. https://doi. org/10.1890/13-0133.1

Chumak V., Obrist M.K., Moretti M., Duelli P., 2015. Arthopod diversity in pristine vs. managed beech forests in Transcarpathia (Western Ukraine). Global Ecology and Conservation 3: 72-82. https://doi.org/10.1016/j. gecco. 2014.11.001

Coddington J.A., Agnarsson I., Miller J.A., Kuntner M., Hormiga G., 2009. Undersampling bias: the null hypothesis for singleton species in tropical arthropod surveys. Journal of Animal Ecology 78(3): 573-584. https://doi.org/10.1111/j.1365-2656.2009.01525.x

Colwell R.K. 2013. EstimateS, version 9.1: Statistical Estimation of Species Richness and Shared Species from Samples (software and User's Guide). Freeware for Windows and MacOs. http://purl.oclc.org/estimates.

Dajoz R., 2000. Insects and forests: The role and diversity of insects in the forest environment. Intercept Limited, Andover, xii +668 p.

Doniţă N., Popescu A., Paucă-Comănescu M., Mihăilescu S., Biriș I.-A., 2005. Habitatele din România [The habitats of Romania]. Vol. 1. Ed. Tehnică Silvică, București, $496 \mathrm{p}$.

Dudley N. (ed.), 2008. Guidelines for applying protected area management categories. Gland, Switzerland: IUCN. $\mathrm{x}+86$ pp. With Stolton S., Shadie P., Dudley N., 2013. IUCN WCPA Best practice guidance on recognising protected areas and assigning management categories and governance types, Best Practice Protected Area Guidelines Series No. 21, Gland, Switzerland: IUCN. X, 86 p. + iv, 31 p.

Dunne J.A., Williams R.J., Martinez N.D., 2002. Food-web structure and network theory: The role of connectance and size. PNAS 99(20): 12917-12922. https://doi. org/10.1073/pnas.192407699

Eckelt A., Müller J., Bense U., Brustel H., Bussler H., Chittaro Y. et al., 2018. "Primeval forest relict beetles" of Central Europe: a set of 168 umbrella species for the protection of primeval forest remnants. Journal of Insect Conservation 22: 15-28. https://doi.org/10.1007/ s10841-017-0028-6

Engelmann H.D., 1978. Zur Dominanzklassifizierung von 
Bodenarthropoden [For the dominance classification of soil arthropods]. Pedobiologia, 18: 378-380.

Franc N., Götmark F., Økland B., Nordénc B., Palttoc H., 2007. Factors and scales potentially important for saproxylic beetles in temperate mixed oak forest. Biological Conservation 135(1): 86-98. https://doi. org/10.1016/j.biocon.2006.09.021

Freude H., Harde K.W., Lohse G.A., 1966. Die Käfer Mitteleuropas [The beetles of Central Europe]. Band 9. Cerambycidae, Chrysomelidae. Goecke \& Evers, Krefeld, 299 p.

Freude H., Harde K.W., Lohse G.A., 1969. Die Käfer Mitteleuropas [The beetles of Central Europe]. Band 8. Teredilia, Heteromera, Lamellicornia. Goecke \& Evers, Krefeld, 388 p.

Freude H., Harde K.W., Lohse G.A., 1971. Die Käfer Mitteleuropas [The beetles of Central Europe]. Band 3. Adephaga 2 - Palpicornia, Histeroidea, Staphylinoidea 1. Goecke \& Evers, Krefeld, 365 p.

Freude H., Harde K.W., Lohse G.A., 1974. Die Käfer Mitteleuropas [The beetles of Central Europe]. Band 5. Staphylinidae II (Hypocyphtinae und Aleocharinae), Pselaphidae. Goecke \& Evers, Krefeld, 381 p.

Freude H., Harde K.W., Lohse G.A., 1979. Die Käfer Mitteleuropas [The beetles of Central Europe]. Band 6. Diversicornia. Goecke \& Evers, Krefeld, 367 p.

Freude H., Harde K.W., Lohse G.A., 1981. Die Käfer Mitteleuropas [The beetles of Central Europe]. Band 10. Bruchidae, Anthribidae, Scolytidae, Platypodidae, Curculionidae. Goecke \& Evers, Krefeld, 310 p.

Freude H., Harde K.W., Lohse G.A., 1983. Die Käfer Mitteleuropas [The beetles of Central Europe]. Band 11. Curculionidae 2. Goecke \& Evers, Krefeld, 342 p.

Freude H., Harde K.W., Lohse G.A., 2009. Die Käfer Mitteleuropas [The beetles of Central Europe]. Band 7. Spektrum-Verlag, Heidelberg. Unveränderter Nachdruck, 310 .

Gerstmeier R., 1998. Checkered beetles. Illustrated key to the Cleridae of the Western Palaearctic. Margraf Verlag, Weikersheim, 241 p. +8 pl.

Gimmel M.L., Ferro M.L., 2018. General overview of saproxylic Coleoptera. In Ulyshen M.D. (ed.), Saproxylic Insects - Diversity, Ecology and Conservation. Zoological Monographs 1, Springer, pp. 51-128.

Girvan M., Newman M.E.J., 2002. Community structure in social and biological networks. PNAS 99(12): 78217826. https://doi.org/10.1073/pnas.122653799

Gossner M., Engel K., Jessel B. 2008. Plant and arthropod communities in young oak stands: are they determined by site history? Biodiversity and Conservation 17: 3165-3180. https://doi.org/10.1007/s10531-008-9418-0

Gossner M.M., Lachat T., Brunet J., Isacsson G., Bouget C., Brustel H. et al., 2013. Current near-to-nature forest management effects on functional trait composition of saproxylic beetles in beech forests. Conservation Biology 27(3): 605-614. https://doi.org/10.1111/ cobi. 12023

Gotelli N.J., Chao A., 2013. Measuring and estimating species richness, species diversity, and biotic similarity from sampling data. In Levin S.A. (ed.), Encyclopedia of Biodiversity, second edition. Academic Press, Waltham, MA, Volume 5, pp. 195-211.

Gotelli N.J., Colwell R.K., 2001. Quantifying biodiversity: procedures and pitfalls in the measurement and comparison of species richness. Ecology Letters 4: 379-391.

Grove S.J., 2002. Saproxylic insect ecology and the sustainable management of forests. Annual Review of Ecology and Systematics 33: 1-23. https://doi. org/10.1146/annurev.ecolsys.33.010802.150507

Guimerá R., Amaral L.A.N., 2005. Functional cartography of complex metabolic networks. Nature 433: 895-900. https://doi.org/10.1038/nature03288

Hammer Ø., Harper D.T., Ryan P.D., 2001. PAST: paleontological statistics software package for education and data analysis. Paleontologia Electronica: http://palaeo-electronica.org

Hedin J., Ranius T., Nilsson S.G., Smith H.G., 2007. Restricted dispersal in a flying beetle assessed by telemetry. Biodiversity and Conservation 17: 675-684. https://doi.org/10.1007/s10531-007-9299-7

Henderson P.A., 2003. Practical methods in ecology. Blackwell Publishing, Oxford, 163 p.

Hickin N.E., 1963. The insect factor in wood decay: an account of wood-boring insects with particular reference to timber indoor. Hutchinson Co. (Publishers) Ltd., London, 336 p.

Hill M., 1973. Diversity and evenness: a unifying notation and its consequences. Ecology 54: 427-432. https://doi. org/10.2307/1934352

Hubbell S.P., 2005. Neutral theory in community ecology and the hypothesis of functional equivalence. Functional Ecology 19(1): 166-172. https://doi.org/10.1111/j.02698463.2005.00965.x

Hurlbert S.H., 1971. The nonconcept of species diversity: a critique and alternative parameters. Ecology 52(4): 577-586. https://doi.org/10.2307/1934145

Hyvärinen E., 2006. Green-tree retention and controlled burning in restoration and conservation of beetle diversity in boreal forests. University of Joensuu, Faculty of Forestry. Dissertationes Forestales 21, 55 p.

Ichim R., 1988. Istoria pădurilor şi silviculturii din Bucovina [History of forests and forestry in Bucovina]. Editura Ceres, Bucureşti, 216 p.

Jonsell M., González Alonso C., Forshage M., van Achterberg C., Komonen A., 2016. Structure of insect community in the fungus Inonotus radiatus in riparian boreal forests. Journal of Natural History, https://doi.or $\mathrm{g} / 10.1080 / 00222933.2016 .1145273$

Jonsell M., Nordlander G., Ehnström B., 2001. Substrate associations of insects breeding in fruiting bodies of wood-decaying fungi. Ecological Bulletins 49: 173194.

Jonsson B.G., Siitonen J., 2012. Dead wood and sustainable forest management. In Stokland J.N., Siitonen J., Jonsson B.G. (eds.), Biodiversity in Dead Wood. Cambridge University Press, Cambridge, pp. 302-337. 
Jordano P., 2010. Coevolution in multispecific interactions among free-living species. Evolution: Education and Outreach 3: 40-46. https://doi.org/10.1007/s12052-009-0197-1

Jost L., 2007. Partitioning diversity into independent alpha and beta components. Ecology 88(10): 2427-2459. https://doi.org/10.1890/06-1736.1

Kirisits T., 2007. Fungal associates of European bark beetles with special emphasis on the ophiostomatoid fungi. In Lieutier F., Day K.R., Battisti A., Grégoire J.-C., Evans H.F. (eds.), Bark and wood boring insects in living trees in Europe - A synthesis. Springer, pp. 181-235.

Koch K., 1989. Die Käfer Mitteleuropas. Ökologie. [The beetles of Central Europe. Ecology]. Band 1. Goecke \& Evers, Krefeld, 440 p.

Koch K., 1989. Die Käfer Mitteleuropas. Ökologie [The Evers, Krefeld, 382 p.

Koch K., 1992. Die Käfer Mitteleuropas. Ökologie [The beetles of Central Europe. Ecology]. Band 3. Goecke \& Evers, Krefeld, 389 p.

Komonen A., Kouki J., 2005. Occurrence and abundance of fungus-dwelling beetles (Ciidae) in boreal forests and clearcuts: habitat associations at two spatial scales. Animal Biodiversity and Conservation 28(2): 137-147.

Kostanjsek F., Sebek P., Baranova B., Seric Jelaska L., Riedl V., Cizek L., 2018. Size matters! Habitat preferences of the wrinkled bark beetle, Rhysodes sulcatus, the relict species of European primeval forests. Insect Conservation and Diversity. https://doi. org/10.1111/ icad.12295

Kunttu P., Junninen K., Kouki J., 2015. Dead wood as an indicator of forest naturalness: A comparison of methods. Forest Ecology and Management 353: 30-40. https://doi.org/10.1016/j.foreco.2015.05.017

Lachat T., Wermelinger B., Gossner M.M., Bussler H., Isacsson G., Müller J., 2012. Saproxylic beetles as indicator species for dead-wood amount and temperature in European beech forests. Ecological Indicators 23: 323-331. https://doi.org/10.1016/j.ecolind.2012.04.013

Lassauce A., Paillet Y., Jactel H., Bouget C., 2011. Deadwood as a surrogate for forest biodiversity: metaanalysis of correlations between deadwood volume and species richness of saproxylic organisms. Ecological Indicators 11: 1027-1039. https://doi.org.10.1016/j. ecolind. 2011.02.004

Lohse G.A., Lucht W.H., 1989. Die Käfer Mitteleuropas [The beetles of Central Europe]. Band 12 - 1 . Supplementband mit Katalogteil. Goecke \& Evers, Krefeld, 346 p.

Lohse G.A., Lucht W.H., 1992. Die Käfer Mitteleuropas [The beetles of Central Europe]. Band 13 - 2 . Supplementband mit Katalogteil. Goecke \& Evers, Krefeld, 375 p.

Lohse G.A., Lucht W.H., 1994. Die Käfer Mitteleuropas [The beetles of Central Europe]. Band 14 - 3. Supplementband mit Katalogteil. Goecke \& Evers, Krefeld, 403 p.

Lompe A., 2002. Die Käfer Europas. Ein Bestimmungswerk im Internet [The beetles of Europe. A determination work on the Internet]. www.coleo-net.de/coleo/index.htm

Longino J.T., Coddington J., Colwell R.K., 2002. The ant fauna of a tropical forest: estimating species richness in three different ways. Ecology 83: 689-702. https://doi. org/10.1890/0012-9658(2002)083[0689:TAFOAT]2.0.CO;2

Lucht W.H., Klausnitzer B., 1998. Die Käfer Mitteleuropas [The beetles of Central Europe]. Band 15 - 4. Supplementband. Goecke \& Evers, Krefeld, 398 p.

MacArthur R.H., 1957. On the relative abundance of bird species. Proceedings of the National Academy of Sciences USA 3: 293-295.

Magurran A.E., 2004. Measuring biological diversity. Blackwell Publishing, Oxford, 256 p.

Magurran A.E., 2005. Species abundance distributions: pattern or process. Functional Ecology 19: 177-181.

Magurran A.E., 2008. Diversity over time. Folia Geobotanica 43:319-327. https://doi.org/10.1007/ s12224-008-9013-x

Margalef R., 1972. Homage to Evelyn Hutchinson, or why is there an upper limit to diversity. Transactions of the Connecticut Academy of Arts and Sciences 44: 211-235.

Martikainen P., Kouki J., 2003. Sampling the rarest: threatened beetles in boreal forest biodiversity inventories. Biodiversity and Conservation 12: 1815-1831.

May R.M., 1973. Stability and complexity in model ecosystems. Princeton University Press, Princeton, N.J., 255 p.

May R.M., 1975. Patterns of species abundance and diversity. In Cody M.L., Diamond J.M. (eds.), Ecology and evolution of communities. Harvard University Press, Cambridge, pp. 81-120.

Mayers C.G., McNew D.L., Harrington T.C., Roeper R.A., Fraedrich S.W., Biedermann P.H. et al., 2015. Three genera in the Ceratocystidaceae are the respective symbionts of three independent lineages of ambrosia beetles with large, complex mycangia. Fungal Biology 119(11): 1075-1092. https://doi.org/10.1016/j.funbio. 2015.08.002

Morris K., Caruso T., Buscot F., Fischer M., Hancock C., Maier T.S., et al. 2014. Choosing and using diversity indices: insights for ecological applications from German Biodiversity Exploratories. Ecology and Evolution 4(18): 3514-3524. https://doi.org/10.1002/ ece 3.1155

Mrvar A., Batagelj V., 2016. Analysis and visualization of large networks with program package Pajek. Complex Adaptive Systems Modeling 4: 6. https://doi. org/10.1186/s40294-016-0017-8

Müller J., Bussler H., Bense U., Brustel H., Flechtner G., Fowles A. et al., 2005. Urwald relict species Saproxylic beetles indicating structural qualities and habitat tradition. Waldoekologie online 2: 106-113.

Müller J., Bussler H., Kneib T., 2008. Saproxylic beetle assemblages related to silvicultural management intensity and stand structures in a beech forest in Southern Germany. Journal of Insect Conservation 12: 107-124. https://doi.org/10.1007/s10841-006-9065-2

Muona J., 1999. Trapping beetles in boreal coniferous forest - how many species do we miss? Entomologica 
Fennica 177: 11-16.

Newman M.E., 2003. The structure and function of complex networks. SIAM Review 45(2): 167-256. https://doi.org/10.1137/ S003614450342480

Nieto A., Alexander, K.N.A., 2010. European red list of saproxylic beetles. Publications Office of the European Union, Luxembourg, viii $+44 p$.

Nikitsky N.B., Schigel D.S., 2004. Beetles in polypores of the Moscow region, Russia: checklist and ecological notes. Entomologica Fennica 15: 6-22.

Nitzu E., Olenici N., 2009. The first study on the beetle fauna in the Giumalau spruce primeval forest (Eastern Carpathians, Romania), mainly based on a quantitative analysis of terrestrial and saproxylic species. In Buse J., Saproxylic beetles - their role and diversity in European woodland and tree habitats. Proceedings of the 5th Symposium and Workshop on the Conservation of Saproxylic Beetles. Pensoft, Sofia-Moscow, pp. 27-48.

Olenici N., Knížek M., Olenici V., Duduman M.-L., Biriş I.-A., 2014. First report of three scolytid species (Coleoptera: Curculionidae, Scolytinae) in Romania. Annals of Forest Research 57(1): 87- 95. https://doi. org/10.15287/afr.2014.196

Olesen J.M., Bascompte J., Dupont Y.L., Jordano P., 2007. The modularity of pollination networks. PNAS 104 (50): 19891-19896. https://doi.org/10.1073/ pnas.0706375104

Parisi F., Pioli S., Lombardi P., Fravolini G., Marchetti M., Tognetti R. 2018. Linking dead wood traits with saproxylic invertebrates and fungi in European forests - a review. iForest 11: 423-436. https://doi.org/10.3832/ ifor2670-011

Patil G.P., Taillie C., 1979. An overwiev of diversity. In Grassle J.F., Patil G.P., Smith W., Taillie C. (eds.), Ecological diversity in theory and practice. International Co-operative Publishing House, Fairland, Md., pp. 3-27.

Pfeffer A., 1995. Zentral- und westpaläarktische Borken- und Kernkäfer. Coleoptera: Scolytidae, Platypodidae [Central and West Palearctic bark and pinhole borer beetles. Coleoptera: Scolytidae, Platypodidae]. Pro Entomologia, c/o Naturhistorisches Museum Basel, 310 p.

Quinto J., Marcos-Garcia M.A., Diaz-Castellazo C., RicoGray V., Brustel H., Galante E., Micó E., 2012. Breaking down complex saproxylic communities: understanding sub-networks structure and implications to network robustness. PLOS ONE 7(9): e54082. https://doi. org/10.1371/journal.pone.0045062

R Core Team, 2015. R: A language and environment for statistical computing. R Foundation for Statistical Computing, Vienna, Austria. URL http://www.R-project.org/

Rabinowitz D, 1981. Seven forms of rarity. In Synge H. (ed.), The Biological aspects of rare plant conservation. John Wiley \& Sons, Somerset, NJ, pp. 205-217.

Radu S., 2007. The ecological role of deadwood in natural forests. In Gafta D., Akeroyd J. (eds.), Nature Conservation: Concept and Practice. Springer, Berlin, pp. 137-141.

Ramírez-Hernández A., Martínez-Falcón A.P., Micó E., Almendarez S., Reyes-Castillo P., Escobar F., 2019.
Diversity and deadwood-based interaction networks of saproxylic beetles in remnants of riparian cloud forest. PLoS ONE 14(4): e0214920. https://doi.org/10.1371/ journal. pone. 0214920

Rényi A., 1961. On measure of entropy and information. In: Neyman J. (ed.), Proceedings of the 4th Berkeley Symposium on Mathematical Statistics and Probability, Vol. I, University of California Press, Berkeley, pp. 547-561.

Rodríguez-Gironés M.A., Santamaría L., 2006. A new algorithm to calculate the nestedness temperature of presence-absence matrices. Journal of Biogeography 33: 924-935. https://doi.org/10.1111/j.1365-2699.2006. 01444.x

Schlosser R.G., Wagner G.P., 2004. Modularity in development and evolution. Univeristy of Chicago Press, Chicago, 600 p.

Schmidl J., Bussler H., 2004. Ökologische Gilden xylobionter Käfer Deutschlands. Einsatz in der landschaftsökologischen Praxis - ein Bearbeitungsstandard [Ecological guilds of xylobiontic (saproxylic) beetles in Germany and their use in landscape ecological surveys - A methodical standard]. Naturschutz und Landschaftsplanung 36(7): 202-218.

Schwarz B., Vázquez D.P., Cara Donna P.J., Knigh T.M., Benadi G., Dormann C.F., et al., 2020. Temporal scaledependence of plant-pollinator networks. Oikos 129(5): 1289-1302. https://doi.org/10.1111/oik.07303

Schwenke W., 1974. Familienreihe Malacodermata [Family series Malacodermata]. In Schwenke W. (ed.), Die Forstschädlinge Europas [The forest pests of Europe]. 2. Band - Käfer [Beetles]. Verlag Paul Parey, Hamburg und Berlin, pp. 10-18.

Seibold S., Bässler C., Baldrian P., Thorn S., Müller J., Gossner M., 2014. Wood resource and not fungi attract early successional saproxylic species of Heteroptera - an experimental approach. Insect Conservation and Diversity 7(6): 533-542. https://doi.org/10.1111/icad.12076

Seibold S., Bässler C., Brandl R., Gossner M.M., Thorn S., Ulyshen M.D., Müller, J. 2015. Experimental studies of dead-wood biodiversity - A review identifying global gaps in knowledge. Biological Conservation 191: 139149. https://doi.org/10.1016/j.biocon.2015.06.006

Shannon C.E., 1948. A mathematical theory of communication. The Bell System Technical Journal 27(3): 379-423.

Shepard R.N., 1966. Metric structures in ordinal data. Journal of Mathematical Psychology 3: 287-315.

Schigel D.S., 2012. Fungivory and host associations of Coleoptera: a bibliography and review of research approaches, Mycology, 3:4, 258-272. https://doi. org/10.1080/ 21501203.2012.741078

Siitonen J., Jonsson B.G., 2012. Other associations with dead woody material. In Stokland J.N., Siitonen J., Jonsson B.G. (eds), Biodiversity in deadwood. Cambridge University Press, Cambridge, pp. 58-81.

Simpson E.H., 1949. Measurement of diversity. Nature 163: 688 .

Song C., Saavedra S., 2020. Telling ecological networks apart by their structure: An environment- 
dependent approach. PLoS Computational Biology 16(4): e1007787. https://doi.org/10.1371/journal. pcbi. 1007787

Speight M.C.D., 1989. Saproxylic invertebrates and their conservation. Nature and Environment Series, No. 42. Council of Europe, Strasbourg, 79 p.

Stokland J.N., 2012. The saproxilic food web. In Stokland J.N., Siitonen J., Jonsson B.G. (eds.), Biodiversity in dead wood. Cambridge University Press, Cambridge, pp. 28-57.

Stokland J.N., Siitonen J., 2012. Species diversity of saproxylic organisms. In Stokland, J.N., Siitonen J., Jonsson, B.G. (eds.), Biodiversity in dead wood. Cambridge University Press, Cambridge, pp. 248-274.

Stokland J.N., Siitonen J., Jonsson B.G., 2012. Biodiversity in dead wood. Cambridge University Press, Cambridge, 524 p. https://doi.org/10.1017/CBO9781139025843

Stugren B., 1982. Bazele ecologiei generale [The basics of general ecology]. Editura Ştiinţifică şi Enciclopedică, Bucureşti, $435 \mathrm{p}$.

Sverdrup-Thygeson A., Gustafsson L., Kouki J. 2014. Spatial and temporal scales relevant for conservation of dead-wood associated species: current status and perspectives. Biodiversity and Conservation 23(3): 513-535. https://doi.org/10.1007/s10531-014-0628-3

Teodosiu M., 2014a. Naturalitatea pădurii: concepte, caracteristici și implicații asupra conservării [Forest naturalness: concepts, characteristics and implications for conservation]. Bucovina Forestieră 14(1): 68-76.

Teodosiu M., 2014b. Evaluarea naturalității și a structurii arboretelor în rezervațiile Pădurea Voievodeasa și Codrul Secular Loben din Obcinele Bucovinei [Evaluation of stand naturalness and structure in forest reserves Pădurea Voievodeasa and Codrul Secular Loben from Obcinele Bucovinei]. Bucovina Forestieră 14(2): 173-184.

Tóthmérész B., Magura T., 2005. Diversity and scalable diversity characteristics. European Carabidology. Proceedings of the $1^{\text {st }}$ European meeting 2003. DIAS Report no. 114: 353-368.

Tylianakis J.M., Laliberte' E., Nielsen A., Bascompte J., 2010. Conservation of species interaction networks. Biological Conservation 143: 2270-2279. https://doi. org/10. 1016/j.biocon.2009.12.004

Ulrich W., 2008. Nestedness - a FORTRAN program for measuring order and disorder in ecological communities. Version 2.0 http://www.home.umk.pl/ $\sim$ ulrichw/Downloads/NestednessManual.pdf

Ulyshen M.D. (ed.), 2018. Saproxylic Insects - Diversity, Ecology and Conservation. Zoological Monographs 1, Springer, $904 \mathrm{p}$.

Vásquez D.P., Chacoff N.P., Cagnolo L., 2009. Evaluating multiple determinants of the plant- animal mutualistic networks. Ecology 90(8): 2039-2046. https://doi. org/10.1890/08-1837.1
Volkov I., Banavar J.R., He F., Hubbell S.P., Maritan A., 2005. Density dependence explains tree species abundance and diversity in tropical forests. Nature 438: 658-661. https://doi.org/10.1038/nature04030

Wende B., Gossner M.M., Grass I., Arnstadt T., Hofrichter M., Floren A., et al. 2017. Trophic level, successional age and trait matching determine specialization of deadwood-based interaction networks of saproxylic beetles. Proceedings of The Royal Society B: Biological Sciences 284: 20170198. https://doi.org/10.1098/ rspb.2017.0198

Whittaker R.H., 1965. Dominance and diversity in land plant communities: numerical relations of species express the importance of competition in community function and evolution. Science 147: 250-260. https:// doi.org/10.1126/science.147.3655.250

Witkowski Z.J., Król W., Solarz W. (eds.), 2003. Carpathian list of endangered species. WWF and Institute of Nature Conservation, Polish Academy of Sciences, Vienna-Krakow, xiii +64 p.

Zaharia L., 2006. List of elaterid species (Coleoptera: Elateridae) from Romania. Complexul Muzeal de Ştiințele Naturii "Ion Borcea" Bacău, Sudii și Cercetări 21: 284-292.

Zicha O. (ed.), 1999-2021. BioLib. http://www.biolib.cz

\section{Supporting Information}

Annex 1: Table 1S. Abundances and proportional representation of Coleoptera families captured in window traps, Voievodeasa Forest; Table 2S. Saproxylic insect species from nature reserve Voievodeasa Forest; Table 3S. Mean values of selected richness and diversity indices characterizing the community of saproxylic beetles in Voievodeasa nature reserve, at different sampling dates and on cumulated data.

Annex 2: Table 4S. Mean values of selected richness and diversity indices characterizing the community of saproxylic beetles in Voievodeasa nature reserve, at different sampling dates and on cumulated data.

Annex 3: Figure 1S. Bipartite networks of the main beetle trophic guilds captured in flight interception traps (Voievodeasa beech, spruce and fir forest, nature reserve). 